\title{
Methyl jasmonate treatment affects the regulation of the 2-C-methyl-D- erythritol 4-phosphate pathway and early steps of the triterpenoid biosynthesis in Chlamydomonas reinhardtii
}

\author{
Audrey S. Commault ${ }^{1}$, Michele Fabris ${ }^{1,2}$, Unnikrishnan Kuzhiumparambil ${ }^{1}$, Jack Adriaans ${ }^{1}$, \\ Mathieu Pernice ${ }^{1}$ and Peter J. Ralph ${ }^{1}$. \\ ${ }^{1}$ University of Technology Sydney, Climate Change Cluster, Ultimo NSW 2007, Australia \\ ${ }^{2}$ CSIRO, Synthetic Biology Future Science Platform, Brisbane QLD 4001, Australia.
*Corresponding author at: University of Technology Sydney, Climate Change Cluster, Ultimo NSW 2007, Australia. \\ Email: audrey.commault@uts.edu.au
}




\section{Highlights}

- First report of triterpenoid elicitation by a phytohormone in C. reinhardtii

- MeJA treatment $(1 \mathrm{mM})$ arrested the growth and up-regulated genes of the MEP pathway

- Highlighting a specialised pathway branching immediately upstream of cycloartenol

- Accumulation of an uncharacterised triterpenoid secondary metabolite $\left(\mathrm{C}_{30} \mathrm{H}_{52} \mathrm{O}_{3}\right)$

- Plant-like MeJA response machinery is putatively absent in C. reinhardtii 


\begin{abstract}
\end{abstract}
Terpenoids are a large and diverse class of naturally occurring metabolites serving many industrial applications and natural roles. Economically important terpenoids are often produced in low abundance from their natural sources, making their industrial-scale production challenging or uneconomical, therefore engineered microorganisms are frequently used as heterologous production platforms. Photosynthetic microorganisms, such as the green alga Chlamydomonas reinhardtii, represent promising systems to produce terpenoids in a cost-effective and sustainable manner, but knowledge about the regulation of their terpenoid metabolism remains limited. Here we report on the investigation of the phytohormone methyl jasmonate (MeJA) as elicitor of algal terpenoid synthesis. We treated C. reinhardtii cells in mid-exponential growth phase with three different concentrations of MeJA $(0.05,0.5$ and $1 \mathrm{mM})$. The highest concentration of MeJA affected the photosynthetic activity of the cells, arrested the growth and up-regulated key genes of the 2-C-methyl-D-erythritol 4-phosphate (MEP) pathway, leading to a significant increase in intermediates of this pathway, squalene and $(S)$-2,3-epoxysqualene, while the abundance of cycloartenol, and two main sterols (ergosterol and 7-dehydroporiferasterol) decreased. These data suggest the redirection of the carbon flux towards the synthesis of yet uncharacterised triterpenoid secondary metabolites upon MeJA treatment. Our results offer important new insights into the regulation of the triterpenoid metabolism in C. reinhardtii and raise important questions on hormonal signalling in microalgae. Phytohormone treatment is tested for the first time in algae, where it holds great potential for identifying key transcriptional regulators of the MEP pathway as targets for future metabolic engineering studies for improve production of high-value triterpenoids. 
Keywords: microalgae; methyl jasmonate; methyl-D-erythritol 4-phosphate (MEP) pathway; Chlamydomonas reinhardtii; triterpenoids; sterols.

\section{INTRODUCTION}

Terpenoids (isoprenoids) are the largest class of natural compounds, which are involved in a myriad of cellular processes. Their diverse biological activities have found applications in multiple industrial products (pharmaceutics, nutraceutics, agriculture, chemicals, flavours/fragrances, colourants, fuels/fuel additives) [1, 2]. Most commercially relevant terpenoids known today are isolated from higher plants, but their industrial production is often challenging or uneconomical, as they are produced in low abundance and only under specific conditions. Thus, their production and extraction from plants requires large amounts of biomass, the yields can vary significantly from batch to batch and the extraction/purification processes are labour intensive and expensive [2-4]. Further, the chemical synthesis of these compounds, when possible, is often too costly and complex, as correct chirality is usually required [1]. In light of these challenges, bioengineering of microbes for the production of terpenoids in controlled bioreactors has emerged as a viable solution. The model organisms Saccharomyces cerevisiae (yeast) and Escherichia coli (bacteria) are typically chosen as heterologous hosts for terpenoid production due to the relative ease of cultivation, the detailed knowledge of their metabolism and their genetic tractability [1]. The use of these organisms, however, is driven by their well-developed genetic toolbox rather than their terpenoid metabolism [5], as both yeast and bacteria do not naturally synthesise plant metabolites. Moreover, both organisms rely on organic carbon sources for growth; consequently adding cost to the production of industrially relevant terpenoids. In recent years, engineered 
photosynthetic microbial hosts have emerged as a carbon-neutral alternative to commonly used fermentative systems, as they have the ability to convert inorganic carbon $\left(\mathrm{CO}_{2}\right)$ into useful biochemicals [6]. Proof-of-principle heterologous terpenoid expression have been reported for cyanobacteria, the diatom Phaeodactylum tricornutum and the model eukaryotic green microalga Chlamydomonas reinhardtii [7-10]; however, as of today, these organisms are less tractable and often produce lower yields than engineered $E$. coli and yeast. The universal terpenoid precursors isopentenyl diphosphate (IPP) and dimethylallyl diphosphate (DMAPP) are naturally produced via two independently evolved isoprenoid pathways: the mevalonate (MVA) pathway and the methyl-D-erythritol 4-phosphate (MEP) pathway, of which C. reinhardtii only possesses the latter [11]. IPP and DMAPP are then condensed to geranyl diphosphate (GPP), farnesyl diphosphate (FPP) and geranylgeranyl diphosphate (GGPP), which are the 'building blocks' of specialised terpenoids (Figure 1). The heterologous synthesis of terpenoids generally consists in the expression of enzymes or even entire biosynthetic pathways, which connect to endogenous terpenoid metabolism and convert the prenyl phosphate substrates into the desired product $[9,12,13]$. Engineering of upstream terpenoid pathways (MVA and/or MEP) is usually necessary to obtain higher yields [1, 12]. In C. reinhardtii, IPP and DMAPP must be generated entirely from the MEP pathway in the chloroplast (Figure 1). For sustainable and cost-effective production of terpenoids in microalgae, metabolic engineering of the MEP pathway is necessary to increase the flow of carbon towards the production of terpenoids precursors $[7,11]$. However, very little is known about the MEP pathway regulation and the mechanisms of IPP and DMAPP transport in $C$. reinhardtii. A number of promising strategies have been suggested for MEP pathway deregulation in photosynthetic microorganisms, such as the inhibition of competing metabolic pathways, gene over-expression, screening of enzyme variants with increased activity, enzyme fusions and inhibition of post-translational events [7, 14]. In this study, we 
investigated a plant hormone, methyl jasmonate (MeJA), as a potential elicitor of the MEP pathway in C. reinhardtii. Plants produce MeJA as a signalling compound in response to biotic and abiotic stresses (e.g., pathogen attack, herbivory and wounding), triggering a complex signalling cascade that rapidly reprograms cell metabolism and physiology for defence $[15,16]$. MeJA is a well-known elicitor of secondary metabolism in plant tissues and exogenous treatment with this hormone has been shown to trigger the biosynthesis of all three major classes of secondary metabolites (i.e. terpenoids, phenylpropanoids/flavonoids, and alkaloids) involved in development and defence mechanisms [3, 17-21]. In higher plants, MeJA is known to upregulate the MEP pathway $[22,23]$ and has been used as an elicitor to increase the production of high-value terpenoids, such as the synthesis of the anti-cancer agent paclitaxel (Taxol®) in suspension cultures of Taxus cell [24].

Although naturally occurring jasmonate signalling has never been reported in microalgae, one study has examined the effect of MeJA on the primary metabolism of C. reinhardtii cells, showing a profound perturbation of the central carbon flux and saturated fatty acid metabolism [25]; however, the effect of MeJA on the production of terpenoids by $C$. reinhardtii remains unexplored. Here, we thoroughly investigated the effects of the plant hormone on the production of triterpenoids and isoprenoids precursors in C. reinhardtii. This study is one of the first attempts aiming to elucidate the regulation of terpenoid metabolism in C. reinhardtii. It sets the basis of future metabolic engineering works for the heterologous production of terpenoids in algae. In the long-term, the knowledge generated will contribute towards the sustainable production of terpenoids in microalgae. 


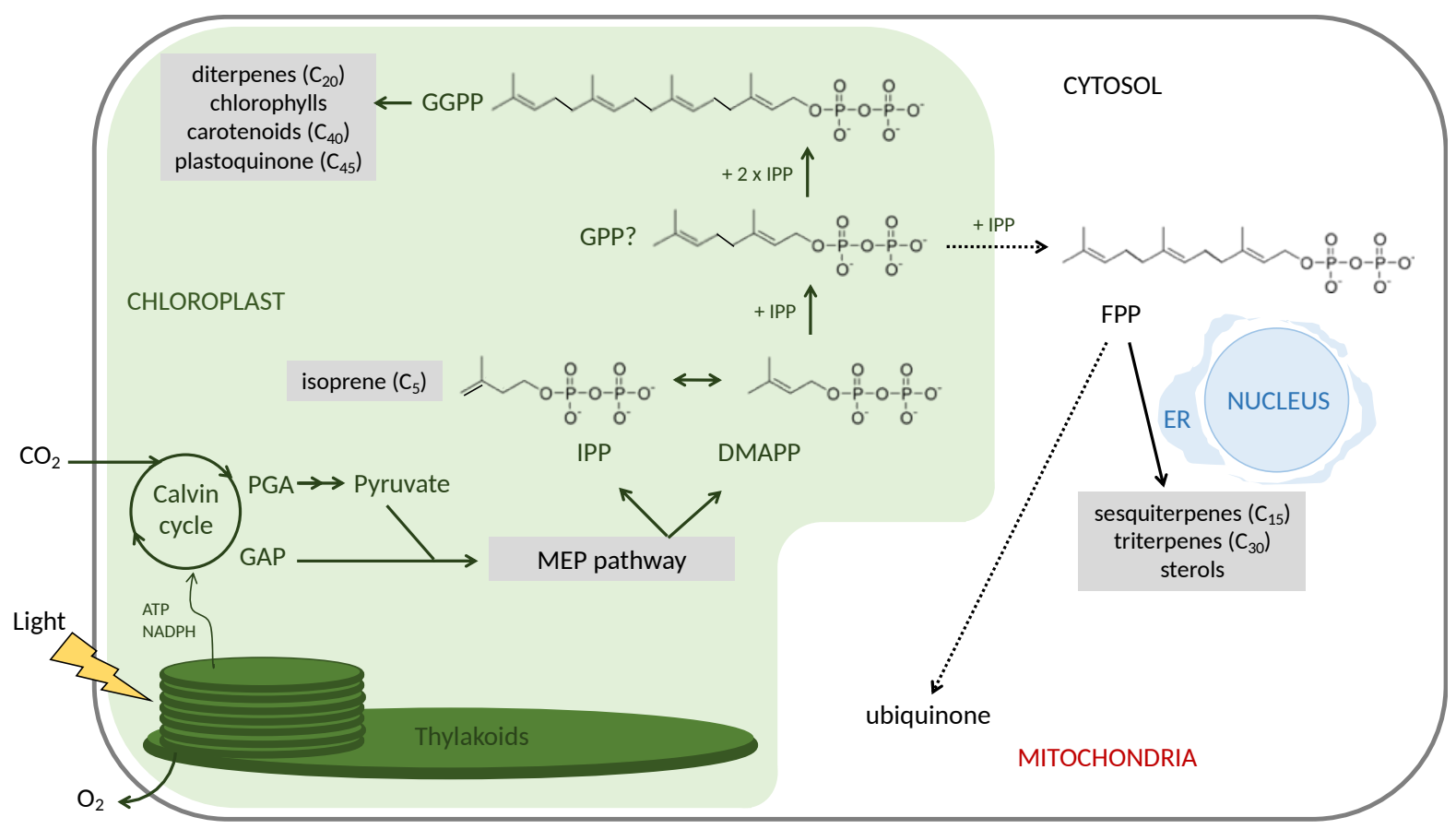

Figure 1. Overview of terpenoid biosynthesis in $C$. reinhardtii. The enzymes of the methylerythritol 4-phosphate (MEP) pathway are nucleus-encoded and post-translationally imported into the chloroplast [11]. The FPP synthase of $C$. reinhardtii is associated with the endoplasmic reticulum [9]. GPP was not detected in this study, therefore a question mark is included. The nature of the transporter(s) responsible for the transfer of prenyl diphosphates accross the plastid membrane is unknown. ER, endoplasmic reticulum; GAP, glyceraldehyde 3-phosphate; PGA, 3-phosphoglyceric acid; DMAPP, dimethylallyl diphosphate; IPP, isopentenyl diphosphate; MEP, methylerythritol 4-phosphate; FPP, farnesyl diphosphate; GGPP, geranylgeranyl diphosphate; GPP, geranyl diphosphate. Adapted from [9, 12].

\section{MATERIALS AND METHODS}

\subsection{Strains and culture conditions}

The Chlamydomonas reinhardtii wild-type strain CC-125 $\mathrm{mt}^{+}[137 \mathrm{c}]$ was cultivated under mixotrophic conditions in Tris-acetate-phosphate (TAP) medium [26] at $26^{\circ} \mathrm{C}$ under continuous illumination using cool white fluorescent lights $\left(50 \pm 10 \mu \mathrm{mol}\right.$ photon $\left.\mathrm{m}^{-2} \mathrm{~s}^{-1}\right)$ with 
constant agitation at $110 \mathrm{rpm}$. The cultures were started at a cell density of $10^{5}$ cells $\mathrm{mL}^{-1}$ in 1L baffled Erlenmeyer flasks.

\subsection{Bioinformatics analysis}

In order to mine for plant-like MeJA response machinery in C. reinhardtii, translated sequences of the Arabidopsis thaliana genes coronatine-insensitive-1 (COI1, AT2G39940.1), the transcription factor MYC2 (AT1G32640), members of the Jasmonate Zim domain family (JAZ1, AT1G19180.1), JAZ2 (At1g74950), JAZ3 (AT3G17860), JAZ6 (AT1G72450), JAZ9 (AT1G70700) and JAZ10 (AT5G13220) were used as query for BLASTp searches conducted on the Chlamydomonas reinhardtii v5.5 proteome in the Phytozome database (https://phytozome.jgi.doe.gov), where the latest (v5.6) gene models are housed, using standard settings, on the 20/12/2018, and for iterative search through Jackhmmr (https://www.ebi.ac.uk/Tools/hmmer/search/jackhmmer) with the standard settings using Hidden Markov Models of each query protein family (Supplementary Material).

\subsection{Methyl jasmonate treatments}

The effect of methyl jasmonate (MeJA) on C. reinhardtii was assessed by treating mid-log phase cultures (cell density of $5 \times 10^{5}-1 \times 10^{6}$ cells $\mathrm{mL}^{-1}$ ) with three different final concentrations of MeJA $(0.05,0.5$ and $1 \mathrm{mM})$. The stock solutions of MeJA were diluted in pure ethanol and prepared so the cultures were all injected with $1 \%(\mathrm{v} / \mathrm{v})$ ethanol, including the controls. Three biological replicates were used per treatment.

\subsection{Automated cell counts}


Samples $(0.5 \mathrm{~mL})$ were extracted from the flasks at 0,12 and 48 hours, fixed with $0.2 \mu \mathrm{m}$ filtered glutaraldehyde at a final concentration of $2 \%$ and stored at $4{ }^{\circ} \mathrm{C}$ in the dark. A $10 \mu \mathrm{L}$ aliquot was pipetted into a haemocytometer (Neubauer, Germany) and viewed under a Nikon Eclipse compound microscope (Nikon, Japan) at $10 \mathrm{x}$ magnification. Cells were allowed to settle into the focal plane for 5 min before 12 images of haemocytometer squares were recorded (Nikon DS-Qi2). Images were processed on ImageJ software (version 2.0) using a custom script to calculate number of cells $\mathrm{mL}^{-1}$.

\subsection{Chlorophyll $a$ fluorescence measurement}

Pulse-amplitude modulated fluorometry (PAM) was used to measure the maximum quantum yield of photosystem II ( Fv/Fm calculated as $\mathrm{Fv}=\mathrm{Fm}-\mathrm{Fo}$, where Fo is the minimum fluorescence in the dark and Fm the maximum fluorescence) for rapid assessment of $C$. reinhardtii photosynthetic activity during the experiment, and to monitor for any photosystem stress caused by MeJA treatment. The measurements were taken with a POCKET-PAM (Gademann Instruments GmbH, Germany) after 10 min of dark acclimation. These measurements were performed at room temperature with the following settings: blue light, measuring light intensity $<0.2 \mathrm{mmol}$ photons $\mathrm{m}^{-2} \mathrm{~s}^{-1} \mathrm{PAR}$, saturation pulse intensity of 2,700 $\mu \mathrm{mol}$ photons $\mathrm{m}^{-2} \mathrm{~s}^{-1} \mathrm{PAR}$, and saturation pulse width of $0.6 \mathrm{~s}$.

\subsection{Metabolites extraction and quantification}

\subsubsection{Triterpenoid analysis}

For triterpenoid analysis, $20 \mathrm{~mL}$ of algal culture were harvested at 48 hours after treatment. The cells were pelleted at $4,000 \mathrm{x}$ g for $5 \mathrm{~min}$ at $4{ }^{\circ} \mathrm{C}$, rinsed once with phosphate buffered saline (PBS) $1 \mathrm{x}$ and frozen at $-80^{\circ} \mathrm{C}$. Cells were freeze-dried and the dry weight was 
measured before extracting the metabolites. Extraction and gas chromatography-mass spectrometry (GC-MS) analyses were performed as described in [27].

\subsubsection{Isoprenoid analysis}

For the analysis of 2-C-methyl-D-erythritol 4-phosphate (MEP), 2-C-methyl-D-erythritol-2,4cyclodiphosphate (MEcPP), geranyl diphosphate (GPP), geranylgeranyl pyrophosphate (GGPP) and farnesyl pyrophosphate (FPP), $40 \mathrm{~mL}$ of algal suspension were washed with 160 $\mathrm{mL}$ and $50 \mathrm{~mL}$ of cold PBS, respectively and extracted as described by Canelas et al. [28] using PBS instead of methanol and by keeping the samples at $-2^{\circ} \mathrm{C}$ instead of $-40^{\circ} \mathrm{C}$. Ten $\mu \mathrm{M}$ of Azidothymidine (AZT) was used as internal standard. MEP, MEcPP, GPP, GGPP and FPP were analysed using a previously described LC-MS/MS method with slight modifications [29]. Authentic standards were kindly provided by A/Prof Claudia Vickers (University of Queensland, Australia). Samples were analysed in multiple reaction monitoring mode on a mass spectrometer (Agilent 6490 Triple Quadrupole) with ESI source (negative ion mode). Following transitions were monitored with fragmentor voltage of $380 \mathrm{~V}$. MEP $(\mathrm{m} / \mathrm{z} 520 \rightarrow$ $322,520 \rightarrow 97,520 \rightarrow 79$, collision energy $(\mathrm{CE})-18 \mathrm{eV}), \mathrm{MEcPP}(\mathrm{m} / \mathrm{z} 277 \rightarrow 179,277 \rightarrow$ 97, $277 \rightarrow 79, \mathrm{CE}-15 \mathrm{eV}), \mathrm{GGPP}(\mathrm{m} / \mathrm{z} 449 \rightarrow 431,449 \rightarrow 159,449 \rightarrow 79, \mathrm{CE}-18 \mathrm{eV})$ and FPP $(\mathrm{m} / \mathrm{z} 381 \rightarrow 363,381 \rightarrow 159,381 \rightarrow 79 \mathrm{CE}-15 \mathrm{eV})$. Chromatographic separation was performed on an Agilent 1290 LC system with a Phenomenex C-6 phenyl analytical column $(250 \mathrm{~mm} \times 4.6 \mathrm{~mm}, 5 \mu \mathrm{m})$. The mobile phase, consisted of $20 \mathrm{mmol} / \mathrm{L}$ ammonium hydrogencarbonate solution (A) and Water/Acetonitrile (1:9, v/v) (B), pumped at a flow rate of $1 \mathrm{~mL} / \mathrm{min}$. LC separation was performed using a linear gradient program as follows: $5 \% \mathrm{~B}$ until $1 \mathrm{~min}$, ramped to $100 \% \mathrm{~B}$ at $10 \mathrm{~min}$, held until $12 \mathrm{~min}$, ramped down to $5 \% \mathrm{~B}$ at $6 \mathrm{~min}$ and held until $18 \mathrm{~min}$. Quantification was performed using the five point calibration curve 
plotted using analytical standards. The concentrations were normalized to the internal standard (AZT) and a total of $10^{8}$ cells.

\subsubsection{Pigments analysis}

Extraction of carotenoids (including chlorophyll a, chlorophyll b and $\beta$-carotene) was carried out using $1.5 \mathrm{~mL}$ of chilled HPLC-grade acetone and kept in the dark prior to pigment analysis by HPLC-UV. Samples were vortexed for 30 seconds (x 3 times) and stored at $-20^{\circ} \mathrm{C}$ overnight. Pigment extracts were then filtered through $0.2 \mu \mathrm{m}$ PTFE $13 \mathrm{~mm}$ syringe filters and stored at $-80^{\circ} \mathrm{C}$ until analysis. An Agilent 1290 Infinity LC HPLC System equipped with a binary pump with integrated vacuum degasser, thermostatic column compartment modules, an Agilent 1290 Infinity Autosampler and PDA (photo-diode array) detector was used for analysis. A Zorbax Eclipse XDB C8 HPLC $4.6 \mathrm{~mm} \times 150 \mathrm{~mm}$ and guard column (Agilent) was used by eluting a gradient of tetrabutyl alkylammonium acetate (TBAA) methanol mix (30:70) (Solvent A) and methanol (Solvent B) as follows: 0-22 min, from 5 to $95 \%$ B; $22-29$ min, 95\% B; 29-31 min, 5\% B; 31-40 min, column equilibration with 5\% B. Column temperature was maintained at $55^{\circ} \mathrm{C}$. A complete pigment spectrum $(270$ to $700 \mathrm{~nm})$ was recorded using the PDA detector. Response factor measurement was performed using pigment standards obtained from DHI, Denmark.

\subsection{4. $\mathrm{C}_{30} \mathrm{H}_{52} \mathrm{O}_{3}$ and protopanaxadiol profiling}

Chemical profile of MeJa treated and control C. reinhardtii cells and protopanaxadiol standard $(10 \mu \mathrm{g} / \mathrm{mL}$ in $\mathrm{MeOH})$ were analysed using 6550 iFunnel Q-TOF LC-MS (Agilent Technologies, Santa Clara, CA, USA) equipped with Dual AJS ESI, coupled with an 1260 infinity HPLC system (Agilent Technologies, Santa Clara, CA, USA). Separation was performed at $25^{\circ} \mathrm{C}$ on an Agilent Zorbax Eclipse XDB-C18 column $(150 \times 4.6 \mathrm{~mm}$ i.d., 2.7 
$\mu \mathrm{m})$. The HPLC program consisted of a linear gradient of A (milli-Q water with $1 \%$ formic acid) to B (100\% acetonitrile with $1 \%$ formic acid) over $25 \mathrm{~min}$, followed by isocratic elution at $\mathrm{B}$ at a flow rate of $1 \mathrm{~mL} \mathrm{~min}{ }^{-1}$. Nitrogen was used as the nebulizing gas. Dual Automatic Jet Stream (AJS) Electrospray Ionisation (ESI) source was kept at a voltage of $3500 \mathrm{~V}$ in positive ion mode. Mass spectra were acquired with source conditions as follows: gas temperature $350^{\circ} \mathrm{C}$, drying gas $4 \mathrm{~L} \mathrm{~min}^{-1}\left(\mathrm{~N}_{2}\right)$, nebulizer pressure 35 psi $\left(\mathrm{N}_{2}\right)$ and Vcap 3,500 $\mathrm{V}$, fragmentor $160 \mathrm{~V}$ and skimmer $65 \mathrm{~V}$. The mass range scanned was $70-1100 \mathrm{~m} / \mathrm{z}$.

\subsection{Gene expression (qPCR)}

The present study conforms to the Minimum Information for Publication of Quantitative Real-Time PCR guidelines [30]. In this section, we indicate the essential information, sensu Bustin et al. (2009), required to allow reliable interpretation of the corresponding RT-qPCR results.

\subsubsection{Primer design}

The transcript sequences coding for the enzymes of the methylerythritol phosphate (MEP) pathway, the FPP synthase (FPPS), the cycloartenol synthase (CAS), the squalene monooxygenase, the sterol C-14 demethylase (CYP51), and delta14-sterol reductase (EGR4/24) were obtained from the Phytozome Chlamydomonas reinhardtii v5.5 database (https://phytozome.jgi.doe.gov). The transcript sequences were blasted for functional domains (Blastx, https://blast.ncbi.nlm.nih.gov/Blast.cgi), which were used as template to design sequence-specific primers for RT-qPCR using the software Primer3 version 4.1.0 (http://bioinfo.ut.ee/primer3/; Table 1) [31]. 
Table 1. Sequence-specific primers used in this study for RT-qPCR analysis. Target

name, $C$. reinhardtii gene IDs, primers sequences, amplicons length, melting

temperatures, and RT-qPCR efficiencies are indicated. DXS: 1-deoxy-D-xylulose 5-

phosphate synthase; DXR: 1-deoxy-D-xylulose 5-phosphate reductoisomerase; CMK: 4-

(cytidine 5'-diphospho)-2-C-methyl-D-erythritol kinase; MDS: 2-C-methyl-D-erythritol 2,4cyclodiphosphate synthase; IDI: Isopentenyl-diphosphate Delta-isomerase; FPPS: Farnesyl pyrophosphate synthase; SQE: Squalene epoxidase; CAS: Cycloartenol synthase; CYP51: sterol C-14 demethylase; ERG4/24: delta14-sterol reductase; CBLP: Chlamydomonas $\beta$ subunit-like polypeptide; RPL13: ribosomal protein L13; RPL10a: ribosomal protein L10a.

\begin{tabular}{|c|c|c|c|c|c|c|c|}
\hline Name & Gene ID/Reference & $\begin{array}{l}\text { Enzymatic } \\
\text { function }\end{array}$ & $\begin{array}{l}\text { Primer forward } \\
\text { sequence }\end{array}$ & $\begin{array}{l}\text { Primer reverse } \\
\text { sequence }\end{array}$ & $\begin{array}{l}\text { Length } \\
\text { (bp) }\end{array}$ & $\begin{array}{l}\mathrm{Tm} \\
\left({ }^{\circ} \mathrm{C}\right)\end{array}$ & $\begin{array}{l}\text { Efficiency } \\
(\%)\end{array}$ \\
\hline DXS & Cre07.g356350.t1.1 & Putative & $\begin{array}{l}\text { ACGTTGTCCAGAA } \\
\text { GGCAACT }\end{array}$ & $\begin{array}{l}\text { GATGAGGTCGTC } \\
\text { CAGGTTGT }\end{array}$ & 137 & 59.8 & 99.9 \\
\hline DXR & Cre12.g546050.t1.2 & Putative & $\begin{array}{l}\text { GAGTTCCCCGACA } \\
\text { AGTTCAA }\end{array}$ & $\begin{array}{l}\text { ATCCTTCACAGC } \\
\text { CACCATCT }\end{array}$ & 108 & 59.5 & 95.1 \\
\hline CMK & Cre02.g145050.t1.2 & Putative & $\begin{array}{l}\text { GAAGCCTCAGCAG } \\
\text { GATTACG }\end{array}$ & $\begin{array}{l}\text { GACCGCCTCTTC } \\
\text { CAACATAA }\end{array}$ & 102 & 60.0 & 98.0 \\
\hline MDS & Cre12.g503550.t1.2 & Putative & $\begin{array}{l}\text { GAGAACATCCGCA } \\
\text { ACAACCT }\end{array}$ & $\begin{array}{l}\text { CAGGCTATCCAC } \\
\text { CTTCTCGT }\end{array}$ & 93 & 59.3 & 100.0 \\
\hline $\mathrm{IDI}^{\dagger}$ & Cre08.g381800.t1.1 & Putative & $\begin{array}{l}\text { GGTGACGCTGACA } \\
\text { CAGGAG }\end{array}$ & $\begin{array}{l}\text { CGTTGTCCTGAA } \\
\text { TCCCTTGT }\end{array}$ & 101 & 60.0 & 98.9 \\
\hline FPPS & Cre03.g207700.t1.1 & Putative & $\begin{array}{l}\text { GGGCCAGTACTTT } \\
\text { CAGATCC }\end{array}$ & $\begin{array}{l}\text { ACTTGTTGTCCT } \\
\text { CGATGTCC }\end{array}$ & 95 & 60.1 & 101.3 \\
\hline SQE & Cre17.g734644.t1.1 & Validated ${ }^{\S}$ & $\begin{array}{l}\text { CAGACGGCGGACT } \\
\text { TTTACAC }\end{array}$ & $\begin{array}{l}\text { CCTTCAGGAATA } \\
\text { CGGTACGC }\end{array}$ & 119 & 59.6 & 100.5 \\
\hline CAS & Cre01.g011100.t1.2 & Putative & $\begin{array}{l}\text { CATCCTGAGCTAC } \\
\text { CAGAACC }\end{array}$ & $\begin{array}{l}\text { GCTGTAGTCCAC } \\
\text { GATGATGT }\end{array}$ & 121 & 59.9 & 96.1 \\
\hline CYP51 & Cre02.g092350.t1.2 & Putative & $\begin{array}{l}\text { TTGATGTGGAGCA } \\
\text { GAAGGTC }\end{array}$ & $\begin{array}{l}\text { GAAATCAACAAC } \\
\text { GCCCGTC }\end{array}$ & 149 & 60.0 & 94 \\
\hline ERG4/24 & Cre02.g076800.t1.2 & Putative & $\begin{array}{l}\text { CTTGCATGGTTTTT } \\
\text { CGGTGT }\end{array}$ & $\begin{array}{l}\text { AAGGCGTTCAGC } \\
\text { TTGTATGT }\end{array}$ & 110 & 60.0 & 79.5 \\
\hline CBLP & Zhao et al., [32] & - & $\begin{array}{l}\text { TGCTGTGGGACCT } \\
\text { GGCTGA }\end{array}$ & $\begin{array}{l}\text { GCCTTCTTGCTG } \\
\text { GTGATGTTG }\end{array}$ & 193 & 61.5 & 100.8 \\
\hline RPL13 & Whitney et al., [33] & - & $\begin{array}{l}\text { AGCACGGCTAGAG } \\
\text { ACAGATG }\end{array}$ & $\begin{array}{l}\text { TAGTGCGTGGCT } \\
\text { GTTTGTTG }\end{array}$ & 115 & 57.0 & 100.0 \\
\hline RPL10a & Pape et al. [34] & - & $\begin{array}{l}\text { CCAAGTGCAGCAT } \\
\text { CAAGTTC }\end{array}$ & $\begin{array}{l}\text { CACGTTCTGCCA } \\
\text { GTTCTTCT }\end{array}$ & 152 & 56.0 & 89.5 \\
\hline
\end{tabular}

${ }^{\dagger}$ IDI is predicted to be present in two different isoforms in C. reinhardtii. The absence of amplification for the second isoform

(Cre11.g467544.t1.1) lead us to focus only on one isoform.

$\ddagger$ Enzymatic function: Validated = experimental evidence at protein level and/or experimental evidence at transcript level; Putative $=$ protein function inferred by homology and/or protein predicted

$\S[35]$ 


\subsubsection{RNA extraction and cDNA synthesis}

For gene expression analysis, $50 \mathrm{~mL}$ aliquots were extracted from the culture flasks at 48 hours. C. reinhardtii cells were pelleted at $4,000 \mathrm{xg}$ for $5 \mathrm{~min}$ at $4^{\circ} \mathrm{C}$, rinsed once with $\mathrm{PBS}$ $1 \mathrm{x}$ and flash frozen in liquid nitrogen. Frozen pellets were stored at $-80{ }^{\circ} \mathrm{C}$ until RNA extraction. The RNA was extracted by adding $1.5 \mathrm{~mL}$ of PureZol (Bio-Rad) to the frozen pellet and pipetting up and down 5 times to homogenize. After 5 min incubation at room temperature, $300 \mu \mathrm{L}$ of chloroform was added. The sample was gently mixed for 15 seconds and incubated at room temperature for $15 \mathrm{~min}$ before being centrifuged at $12,000 \mathrm{x} \mathrm{g}$ for 15 min at $4{ }^{\circ} \mathrm{C}$. The upper phase was recovered and mixed with an equal volume of absolute ethanol. The sample was then transferred to an RNeasy mini spin column provided with the RNeasy Mini Kit (Qiagen) and the rest of the extraction was performed according to manufacturer's instructions. Column purification was carried out to remove gDNA using PureLink $^{\mathrm{TM}}$ DNase (Life Technologies). The RNA quantity was assessed by spectrophotometry (NanoDrop ${ }^{\mathrm{TM}}, 2000$, Thermo Scientific). The quantity of RNA was normalized to $1 \mu \mathrm{g}$ in all the samples, for accurate comparison between treatments, and used for further cDNA synthesis. The cDNA was generated using an iScript cDNA Synthesis Kit (Bio-Rad) following the manufacturer's instructions and stored at $-20{ }^{\circ} \mathrm{C}$.

\subsection{3. $R T-q P C R$}

RT-qPCR gene expression quantification was performed in three technical replicates using iTaq UniverSYBR Green Master Mix (Bio-Rad) on a Real-Time PCR System (CFX384TM, Bio-Rad). A total volume of $10 \mu \mathrm{L}$ per reaction was used with 1:20 dilutions of cDNA from control and treated C. reinhardtii cells and $100 \mathrm{nM}$ of each specific primers (final concentration). The Hard-Shell® 384-Well PCR plates (Bio-Rad) were filled with a robot (epMotion 5075, Eppendorf) and the amplification was performed using the following PCR 
conditions: incubation at $95^{\circ} \mathrm{C}$ for $10 \mathrm{~min}$, then 44 cycles of $95^{\circ} \mathrm{C}, 60^{\circ} \mathrm{C}, 68^{\circ} \mathrm{C}$ for $30 \mathrm{~s}$ each, followed by a melt curve. A "no template" control along with a "no reverse transcription" control were generated for each gene and each treatment to ensure that the PCR reactions were free of genomic DNA contamination. Repeatability of the assay between the technical replicates was consistent across the different genes with the replicate variability falling within the set limit of $<0.5$ cycles for all the sample-gene combinations tested.

\subsubsection{Data acquisition}

The RT-qPCR data were analysed in regression mode using the CFX Manager ${ }^{\mathrm{TM}} 3.1$ Software. The RT-qPCR efficiency for each gene and each treatment was determined against a standard curve (cDNA dilution gradient of 243, 81, 27, 9 and $3 \mathrm{ng}$ ) and a linear regression model [36]. The corresponding RT-qPCR efficiencies were calculated according to the equation described by Radonić et al. [37]:

$P C R$ efficiency $=\left(10^{\left[-\frac{1}{\text { slope }}\right]}-1\right) \times 100$

All of the RT-qPCR efficiencies obtained for the different primers were between 80 and $101 \%$ (Table 1), with a calibration coefficient $>0.95$ as previously recommended [30]. Expression levels of the target genes were normalized against the three reference genes (CBLP, RPL13, RPL10a; Table 1) to obtain Normalized Relative Quantities (NRQ).

\subsection{Statistical analyses}

Statistical analyses were done in GraphPad Prism 5.0 Kolmogorov-Smirnov and Levene'test were used first to confirm normality and homoscedasticity of the data respectively, and parametric tests (ANOVA and unpaired $t$-test) were applied accordingly. Significant effects were then analysed using post-hoc Tukey's HSD test for the cell count and Fv/Fm data, a 
Dunnett's test for the RT-qPCR data and a two-tailed unpaired $t$-test for the metabolite concentrations. The analyses tested the null hypothesis that there was no difference in growth, chlorophyll $a$ fluorescence, gene expression and metabolites abundance between the MeJAelicited and control treatments. The results were considered significant at $\mathrm{P}<0.05$ (Table A1). Throughout the paper, values given are mean $\pm \operatorname{SEM}(\mathrm{n}=3$ biological replicates).

\section{RESULTS AND DISCUSSION}

\subsection{Potential absence of a plant-like MeJA response machinery in $C$. reinhardtii}

Higher plants respond to methyl jasmonate (MeJA) through a complex signalling cascade that triggers profound transcriptional, translational and metabolic reprogramming of cell physiology. In $A$. thaliana the upstream players and regulators of this mechanism include coronatine- insensitive-1 (COI1) factor, cullin-1 (CUL1), the transcriptional regulator MYC2 and members of the Jasmonate Zim domain (JAZ) protein family [38, 39]. The proteome of C. reinhardtii was mined for orthologs or proteins related to COI1, CUL1, MYC2 and JAZ proteins, but no significant matches to the query proteins could be identified, with the exception of a homolog of CUL1 (Cre17.g734400.t1.1). C. reinhardtii possesses at least three members of the Cullin protein family (Cre17.g734400.t1.1, Cre07.g324050.t1.2 and Cre12.g516500.t1.1), which are knowingly involved in protein degradation mechanisms, and widely conserved in eukaryotes [40]. Although it cannot be excluded that a plant-like mechanism of MeJA response involving Cre17.g734400.t1 may exist in C. reinhardtii, the lack of homologues of key components such as COI1, MYC2 and JAZ proteins, based on our computational analysis, suggests that the mechanism might be different. However, when $C$. 
reinhardtii cultures are experimentally treated with sufficient concentration of MeJA, the alga showed a marked physiological and metabolic shift, similar to those generally observed in higher plants [25]. This may suggest the existence of a possibly distinct but convergent MeJA reception and signal transduction mechanism in green algae.

\subsection{Effect of MeJA on cell growth and photosynthetic activity}

The treatment of $C$. reinhardtii cells with $1 \mathrm{mM}$ of MeJA arrested the growth (two-way ANOVA: $\mathrm{F}_{6,16}=7.161, \mathrm{p}=0.0008$; post-hoc Tukey’s HSD $\mathrm{p}<0.0001$; Table A1) and significantly reduced the photosynthetic activity of the cells (two-way ANOVA: $\mathrm{F}_{6,16}=$ 5.623, $\mathrm{p}=0.0026$; post-hoc Tukey’s HSD $\mathrm{p}<0.01$; Table A1). Lower concentrations of MeJA did not show significant effect (Figure 2). After 48 hours of incubation with $1 \mathrm{mM}$ of MeJA the growth was halted but no signs of apoptosis or cell lysis were observed (Figure A1). A study by Lee et al. [25] reported similar results, with a full inhibition of C. reinhardtii growth after treatment with $1 \mathrm{mM}$ of MeJA, while only a partial inhibition was observed at a concentration of $0.5 \mathrm{mM}$. Lee et al. study also indicated that MeJA-mediated growth inhibition was associated with perturbations in central carbon and saturated fatty acid metabolisms of C. reinhardtii. In higher plants, MeJA has been shown to broadly divert carbon allocation from primary metabolism to secondary metabolism [18], which is often accompanied by a decrease in cell growth $[24,41]$. The inhibitory effect of MeJA on plant growth is not attributable to cell death, but rather to perturbations of the cell cycle progression $[15,24,42]$

The maximum quantum yield of photosystem II (PSII) dropped from $0.84 \pm 0.04$ to $0.67 \pm 0.07$ after 12 hours and 48 hours of incubation with $1 \mathrm{mM}$ of MeJA, respectively 
A.

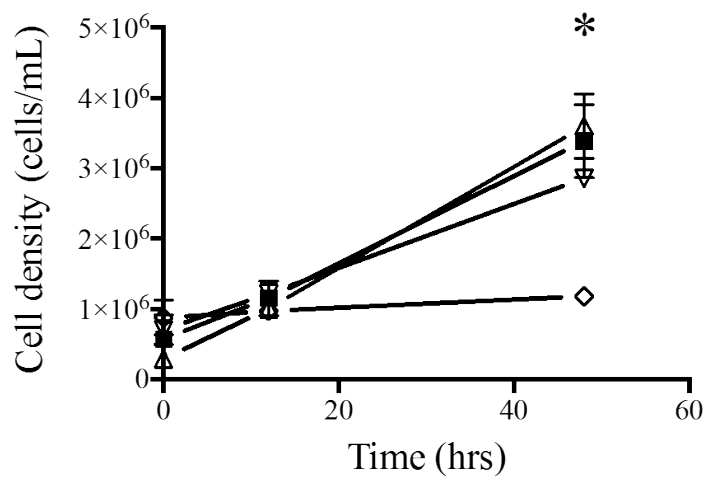

B.

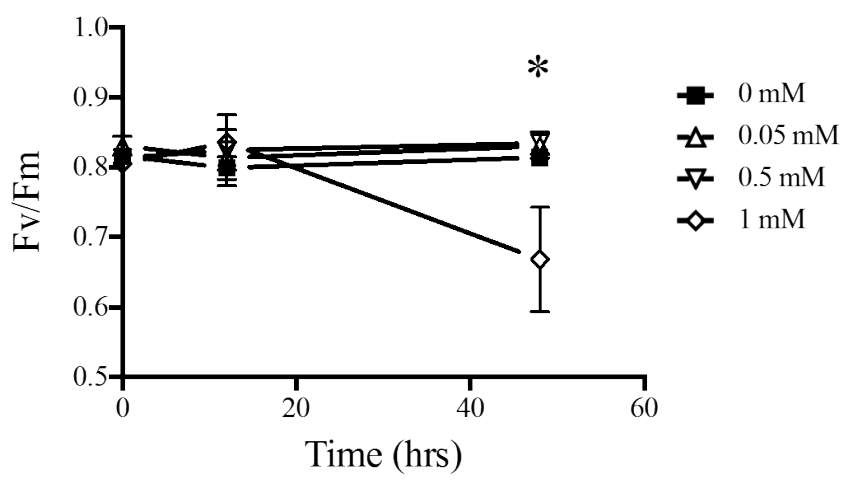

Figure 2. Effect of MeJA concentrations $(0,0.05,0.5$ and $1 \mathrm{mM})$ on the growth $(\mathrm{A})$ and photosynthetic activity (B) of $\boldsymbol{C}$. reinhardtii cells. The initial 0 hour represents the time at which the cells were treated with MeJA. *Significant difference (post-hoc Tukey's HSD, $\mathrm{P}<0.05)$ between the control $(0 \mathrm{mM})$ and the $1 \mathrm{mM}$ treatment. Mean $\pm \mathrm{SEM}$ is shown $(\mathrm{n}=3)$.

\subsection{Transcriptional up-regulation of the MEP pathway in MeJA-elicited microalgae}

Given the elicitory effect of MeJA on terpenoid production in higher plants, we hypothesized that MeJA induces the biosynthesis of terpenoid precursors in C. reinhardtii cells. Isopentenyl 
pyrophosphate (IPP) and dimethylallyl pyrophosphate (DMAPP) are the universal building blocks of all terpenoids. In the absence of the mevalonate (MVA) pathway, these precursors are solely synthesized by the methyl-D-erythritol 4-phosphate (MEP) pathway in $C$. reinhardtii [46]. Therefore, the expression levels of five key genes of the MEP pathway were investigated after exposure to MeJA (Figure 3A). Due to significant effects observed on growth and quantum yield of PSII, gene expression data were collected at 48 hours of MeJA treatment. These genes encode the enzymes 1-deoxy-D-xylulose 5-phosphate synthase (DXS, Cre07.g356350.t1.1), 1-deoxy-D-xylulose 5-phosphate reductoisomerase (DXR, Cre12.g546050.t1.2), 4-(cytidine 5'-diphospho)-2-C-methyl-D-erythritol kinase (CMK, Cre02.g145050.t1.2), 2-C-methyl-D-erythritol 2,4-cyclodiphosphate synthase (MDS, Cre12.g503550.t1.2) and isopentenyl-diphosphate delta-isomerase (IDI, Cre08.g381800.t1.1). Two isoforms of $I D I$ are predicted to be present in C. reinhardtii, but only one was successfully amplified in this case. Concentration of MeJA up to $0.5 \mathrm{mM}$ did not have a significant effect on transcript levels, while the highest concentration of MeJA (1 mM) triggered a clear up-regulation of the genes encoding five key enzymes (Table A1, Figure 3A). Importantly, the over-expression of genes encoding the enzymes up-stream of MEP formation are matched by expression levels of transcripts encoding enzymes downstream of MEP to avoid pathway bottlenecks, especially the "gatekeeper" enzymes DXS and IDI.

DXS and HDR, and to some extent DXR, are known to play a major role in the control of flux in the MEP pathway of higher plants [11, 47, 48]. Transgenic Arabidopsis plants that over- or underexpress DXS respectively accumulated more or less isoprenoids (chlorophylls, tocopherols, carotenoids, abscisic acid, and gibberellins) compared with wild-type plants [49], demonstrating that DXS catalyzes one of the rate-limiting steps of the MEP biosynthetic pathway. In addition to DXS, DXR and HDR enzymes also showed rate-limiting roles in IPP 
and DMAPP synthesis [47]. However, unlike DXS, the regulation of these two enzymes appears to vary among plants and in different conditions. As of today, DXS represents the most obvious target for the manipulation of the isoprenoid metabolism. Enfissi et al. [50] demonstrated a 1.6-fold increase in the carotenoid content of transgenic tomato lines containing a bacterial $d x s$ targeted to the plastid, while a 7-fold increase in phytoene was reported in potato tubers engineered with a bacterial $d x s$ gene [51]. Lauersen et al. [12] observed similar results in C. reinhardtii with the expression of an heterologous DXS (from Salvia pomifera), which increased flux towards heterologous diterpenoids through the MEP pathway. However, simultaneous expression of DXS and the downstream enzyme geranylgeranyl pyrophosphate synthase (GGPPS) as a fusion protein had a similar effect to overproduction of either target alone, suggesting that the cell has a natural tolerance to increased flux through the MEP pathway as long as there is a sink for the end product [12]. The over-expression of heterologous diterpene synthase did not outcompete native mechanisms for GGPP channeling, as the levels of downstream carotenoids and chlorophylls were unchanged [12]. These results indicate that the cell has other mechanisms in place to compensate for modifications in the MEP pathway than transcriptional up-regulation. In other words, small variations in transcript abundances may change flux ratios, but when the cell is responding to a stress other regulations mechanisms such as post-translational regulations can play a major role. In higher plants mutants affected in any particular step of the MEP pathway, low transcript levels of the pathway genes correlates with the low abundance of the corresponding enzymes, except for the DXS and HDR proteins, strongly suggesting a posttranslational regulatory mechanism for these two enzymes [47, 48]. Also, the current study looked mostly at changes in transcripts level following MeJA treatment, regulation at the post-translational level should not be excluded. Especially for DXS, the non-significant 
change in $d x s$ transcript level after treatment with $1 \mathrm{mM}$ MeJA (Figure 3A) could suggest that the regulation happened at a post-translational level.

A.
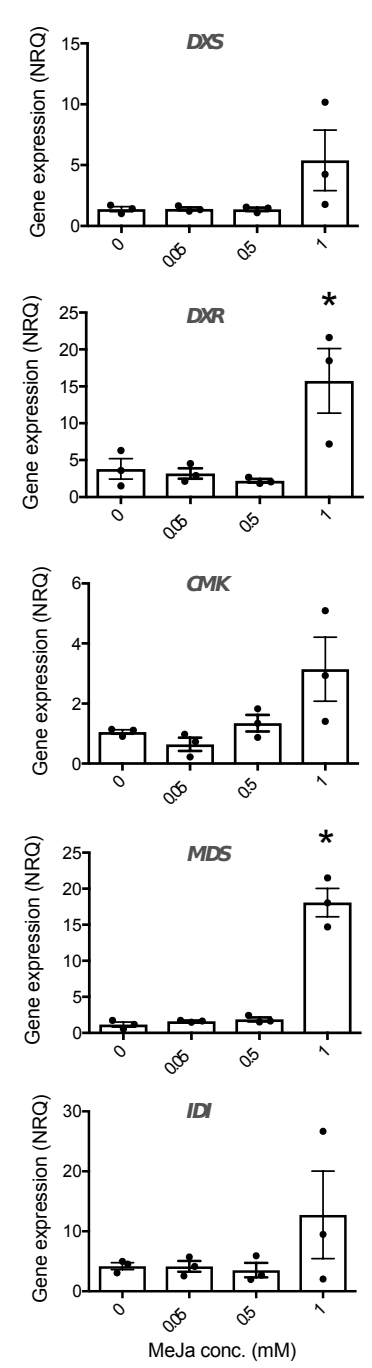

B.
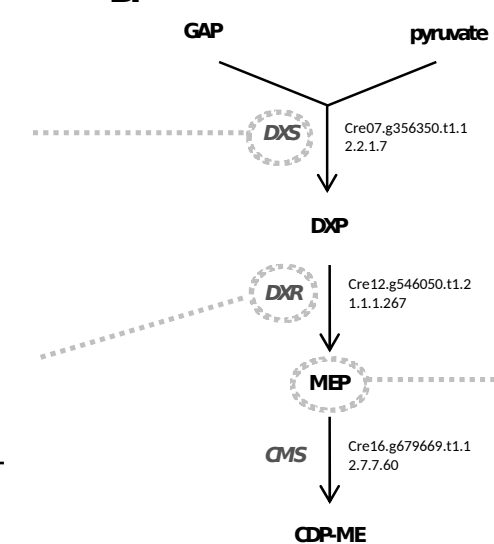

CDRME

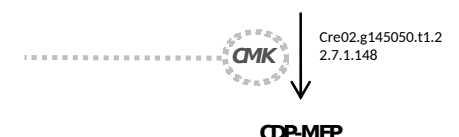

CDP-MP

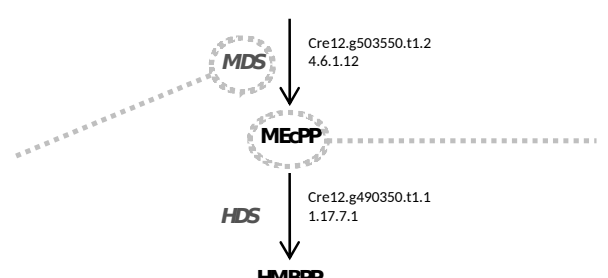

$\underset{\text { HMBPP }}{\downarrow}$

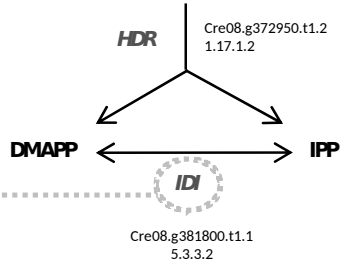

C
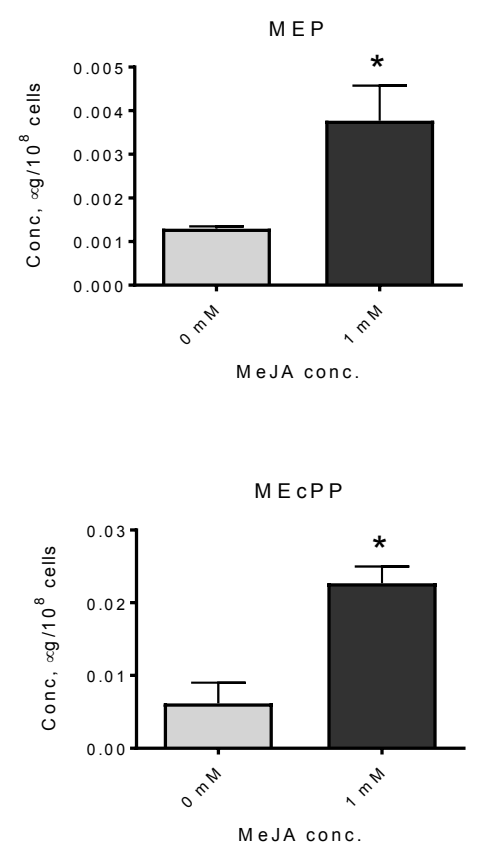

Figure 3. Effect of MeJA on the MEP pathway of $C$. reinhardtii after 48 hours of

treatment. A. Relative expression level (Normalized relative quantity, NRQ) of five genes of the MEP pathway in cells treated with $0,0.05,0.5$ and $1 \mathrm{mM}$ of MeJA, Mean $\pm \mathrm{SEM}, \mathrm{n}=3$, each dot represent a sample. *Significant difference (Dunnett's, $\mathrm{P}<0.05$ ) between the control $(0 \mathrm{mM})$ and the treatment at 48 hours. B. Schematic of the MEP pathway. C. Concentrations of two intermediates in $10^{8}$ cells treated with 0 and $1 \mathrm{mM}$ of MeJA for 48 hours. Lower 
concentrations of MeJA were not investigated here as they did not affect the gene expression. Mean \pm SEM is shown $(\mathrm{n}=3)$ and unpaired $t$-test determine statistical significance between the control $(0 \mathrm{mM})$ and the $1 \mathrm{mM}$ treatment $\left(\mathrm{p}<0.05\left[{ }^{*}\right]\right)$. GAP: D-glyderaldehyde 3 phosphate; $D X S$ : 1-deoxy-D-xylulose 5-phosphate synthase gene; DXP: 1-deoxy-D-xylulose 5-phosphate; DXR: 1-deoxy-D-xylulose 5-phosphate reductoisomerase gene; MEP: 2-Cmethyl-D-erythritol 4-phosphate; $C M S$ : 2-C-methyl-D-erythritol 4-phosphate cytidylyltransferase gene; CDP-ME: 4-(cytidine 5'-diphospho)-2-C-methyl-D-erythritol; CMK: 4-(cytidine 5'-diphospho)-2-C-methyl-D-erythritol kinase gene; CDP-MEP: 2phospho-4-(cytidine 5'-diphospho)-2-C-methyl-D-erythritol; MDS: 2-C-methyl-D-erythritol 2,4-cyclodiphosphate synthase gene; MEcPP: 2-C-methyl-D-erythritol-2,4-cyclodiphosphate; HDS: (E)-4-hydroxy-3-methylbut-2-enyl-diphosphate synthase gene; HMBPP: 1-hydroxy-2methyl-2-(E)-butenyl 4-diphosphate; HDR: 4-hydroxy-3-methylbut-2-enyl diphosphate reductase gene; DMAPP: Dimethylallyl diphosphate; IPP: Isopentenyl diphosphate; IDI: Isopentenyl-diphosphate Delta-isomerase gene.

\subsection{Effect of MeJA on MEP pathway intermediates, prenyl phosphates and pigments}

The increase in gene expression was correlated with an increase in abundance of 2-C-methylD-erythritol 4-phosphate (MEP) and 2- C-methyl-D-erythritol-2,4-cyclodiphosphate (MEcPP), with significantly higher concentrations observed in the MeJA-treated cells than in that of the control (Table A1, Figure 3C). MEP and MEcPP play a central role in the regulation of the MEP pathway and stress response in plants $[52,53]$. In the plastids of higher plant cells, MEP is the first committed precursor of the pathway and activates the expression of $M D S$ gene $[52,54]$. MDS produces MEcPP, which also acts as retrograde signalling 


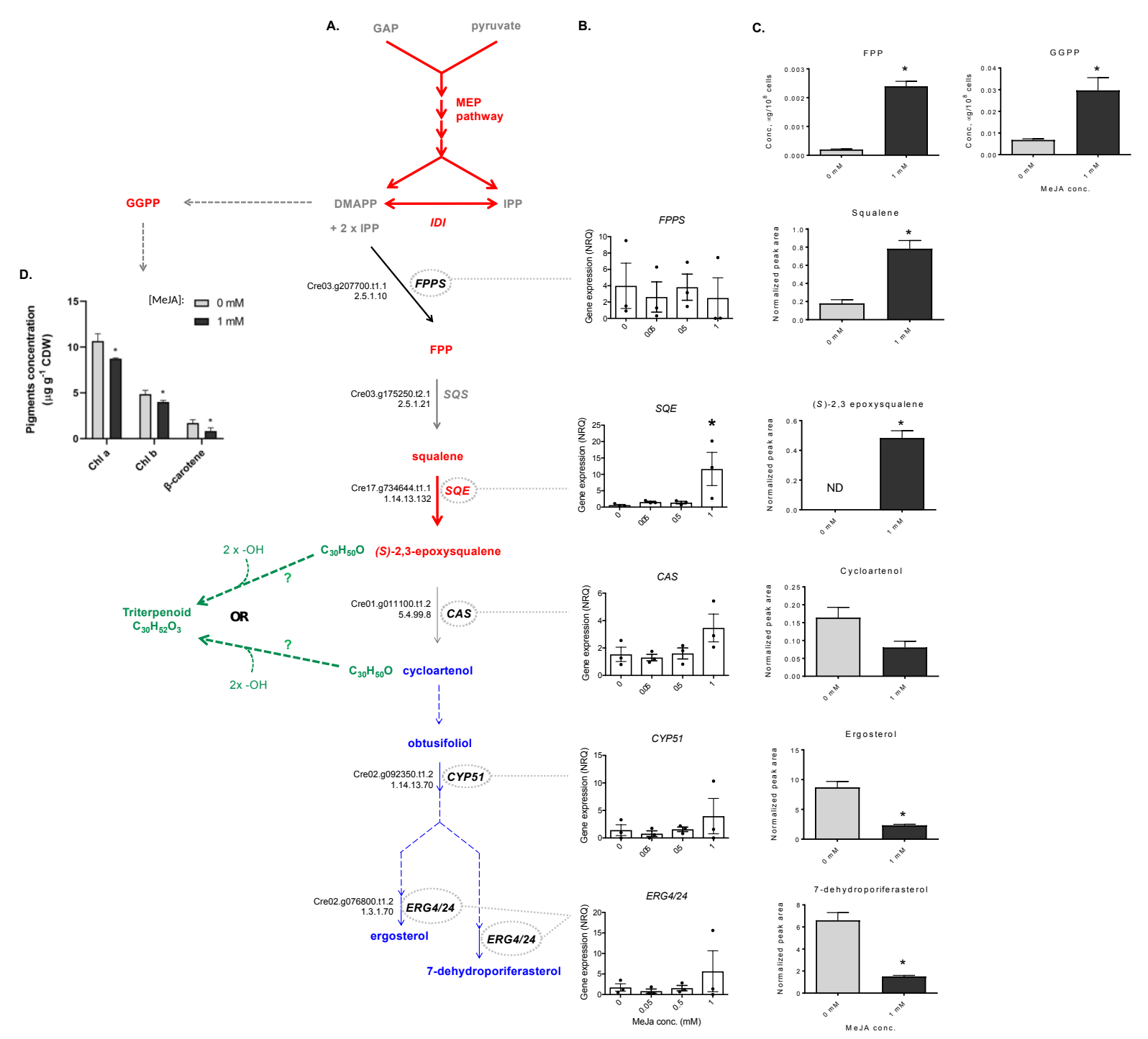

Figure 4. Effect of MeJA on triterpenoid biosynthesis. A. Conceptual diagram of the effect of MeJA on the putative triterpenoid pathway of $C$. reinhardtii. The metabolites and genes 
proven (in this study) to be over-expressed are displayed in red, the downregulated metabolites are in blue. The genes not showing significant regulation are displayed in black. Dashed arrows indicate multiple enzymatic steps. An uncharacterised pathway branch (in green) hypothetically stems from either $(S)$-2,3-epoxysqualene or cycloartenol steps. B. Relative expression level of $S Q E, C A S, C Y P 51$ and $E R G 4 / 24$ in cells treated with $0,0.05,0.5$ and $1 \mathrm{mM}$ of MeJA for 48 hours. Mean $\pm \operatorname{SEM}(\mathrm{n}=3)$. C. Relative quantity of squalene, $(S)$ 2,3-epoxysqualene, cycloartenol, ergosterol and 7-dehydroporiferasterol in the control (0 $\mathrm{mM})$ and the treated cells $(1 \mathrm{mM})$ after 48 hours. ND $=$ Not Detected. Mean \pm SEM is shown $(\mathrm{n}=3)$ and unpaired $t$-test determine statistical significance between the control $(0 \mathrm{mM})$ and the $1 \mathrm{mM}$ treatment $\left(\mathrm{p}<0.05\left[^{*}\right]\right)$. D. Pigment concentrations in control $(0 \mathrm{mM})$ and $1 \mathrm{mM}$ MeJA treated cells after 48 hours of treatment. Mean \pm SEM is shown $(\mathrm{n}=3)$ and unpaired $t$ test determine statistical significance between the control $(0 \mathrm{mM})$ and the $1 \mathrm{mM}$ treatment $(\mathrm{p}$ $<0.05\left[{ }^{*}\right]$ ). GAP: D-glyderaldehyde 3-phosphate; DMAPP: Dimethylallyl diphosphate; IPP: Isopentenyl diphosphate; IDI: Isopentenyl-diphosphate Delta-isomerase gene, FPPS: farnesyl diphosphate synthase gene; GGPPS: geranylgeranyl pyrophosphate synthase gene; GGPP: geranylgeranyl pyrophosphate; FPP: farnesyl pyrophosphate; $S Q S$ : squalene synthase gene, $S Q E$ : squalene epoxidase gene; $C A S$ : cycloartenol synthase gene; CYP51: sterol C-14 demethylase gene; EGR4/24: delta14-sterol reductase gene.

The shift in metabolism towards the production of DMAPP and IPP suggests a possible accumulation of the prenyl phosphates geranyl pyrophosphate (GPP), geranylgeranyl pyrophosphate (GGPP) and farnesyl pyrophosphate (FPP) in the cells treated with MeJA. While GPP was not detected in the samples, the concentrations of FPP and GGPP were significantly higher in the treated cells compare with the control (Figure 4C). C. reinhardtii possesses at least one putative GPP synthase (Cre12.g511700), suggesting that GPP is 


\subsection{Accumulation of triterpenoid precursors and decrease in main sterols}

\section{abundance in MeJA-elicited cells}

C. reinhardtii membranes contain ergosterol and 7-dehydroporiferasterol as main sterols and these are synthesised from squalene, through the formation of cycloartenol, by a pathway that resembles that of higher plants [57]. Squalene, the C30 precursor of triterpenoids, is the result of the condensation of two FPP molecules (Figure 4A). Targeted analyses showed a four-fold accumulation of squalene in the elicited-cells ( $1 \mathrm{mM} \mathrm{MeJA})$ compared to the control 48 hours after treatment (Figure 4C). The increase in squalene was correlated with the increased 
Although the increased accumulation of squalene in C. reinhardtii cells following MeJA treatment was previously reported [25], the present study is the first to demonstrate the effect of MeJA on the up-regulation of $S Q E$ transcripts in C. reinhardtii. According to BLAST searches and knockdown experiments [35], C. reinhardtii only has one conventional SQE (CrSQE), which differs from diatoms and other microalgae. These organisms have recently been determined to use an alternative SQE (AltSQE, [27]). SQE is an important point of regulation and rate-limiting step in sterol and triterpenoid biosynthesis [58]. According to the current literature, most plants have two or more copies of $S Q E$ genes [58]. In Panax ginseng, the two $S Q E$ genes ( $P g S Q E 1$ and $P g S Q E 2)$ have been shown to be differentially regulated by MeJA treatment [58]. While MeJA enhanced the expression of the PgSQE1 gene, which is suspected to contribute to ginsenoside biosynthesis, it did not affect the expression of PgSQE2 gene involved in phytosterol production. Similarly, in Medicago truncatula, one squalene epoxidase gene (MtSQE2) was up-regulated by treatment with MeJA leading to the accumulation of triterpenes, while the sterol composition and the second squalene epoxidase gene (MtQSE1) remained unaffected [59]. In this study, we showed that $C r S Q E$ expression is sensitive to MeJA.

In MeJA treated C. reinhardtii cultures, the increased accumulation of $(S)$-2,3-epoxysqualene was correlated with a decrease in the abundance of the key sterol intermediate cycloartenol, a direct product of the cyclisation of $(S)$-2,3-epoxysqualene catalysed by the cycloartenol synthase (CAS) enzyme, and the two main sterols of C. reinhardtii, ergosterol and 7- 
dehydroporiferasterol (Figure 4). Surprisingly, we detected yet uncharacterised triterpenoidbased molecules in samples treated with MeJA (Figure 5). These compounds eluted at Rt $24.2 \mathrm{~min}(\mathrm{~m} / \mathrm{z} \mathrm{461)}$ and $25.0 \mathrm{~min}(\mathrm{~m} / \mathrm{z} 461)$. High resolution mass spectrometry (HRMS) and fragmentation pattern were indicative of compounds with molecular formula $\mathrm{C}_{30} \mathrm{H}_{52} \mathrm{O}_{3}$, possibly two different isomers (Figure A2). The chemical formula and mass spectrum correspond to protopanaxadiol-type triterpene saponins, which have been shown to be overproduced in Panax ginseng roots treated with MeJA [60, 61]. The peaks were compared to the analytical standard of protopanaxodiol, but the latter eluted at a different retiention time (Figure 5). More work is currently been undertaken to elucidate the structure of these triterpenoid-based molecules. The mass spectrum (Figure A2) reveals that the molecule contains three hydroxyl groups and is likely to be derived from the double hydroxylation of either the $(S)$-2,3-epoxysqualene - as in the case of saponin biosynthesis - or cycloartenol. Both $(S)$-2,3-epoxysqualene and cycloartenol have the same chemical formula $\left(\mathrm{C}_{30} \mathrm{H}_{50} \mathrm{O}\right)$ and a mass of 426 Daltons, which is two hydroxyl groups away from the 460 Daltons molecule. The simultaneous increase in (S)-2,3-epoxysqualene and decrease in cycloartenol content coupled with the accumulation of this new triterpenoid compounds suggests a hypothetical pathway branching that uses either $(S)$-2,3-epoxysqualene or cycloartenol as a substrate (Figure 4). To outline the presence of a putative branching node, the expression of key sterol genes in C. reinhardtii were analysed. Expression data of $C A S$ (Cre01.g011100.t1.2), sterol C-14 demethylase (CYP51, Cre02.g092350.t1.2), and delta14-sterol reductase (EGR4/24, Cre02.g076800.t1.2) genes did not show a clear down or up-regulation as no significant differences with the control $(0 \mathrm{mM})$ were observed (Figure $4 \mathrm{~B}$, Table A1). These inconclusive results did not provide sufficient transcriptomic clues to determine whether the pathway branching occurs right after the conversion of squalene to $(S)-2,3$-epoxysqualene or after the conversion of the latter to cycloartenol. 
Numerous studies performed on higher plants show the same effect with an increased content of triterpenoids directly synthesized from (S)-2,3-epoxysqualene and an associated decrease in sterol synthesis downstream from cycloartenol after treatment with MeJA [59, 62, 63]. Mangas et al. (2006) previously reported that the induction of nor-seco-friedelane galphimines synthesis (triterpenoids derived from (S)-2,3-epoxysqualene) was coupled with the inhibition of sterol synthesis by MeJA in the plant Centella asiatica [62]. In the same plant elicited with MeJA, Kim et al. [63] showed an upregulation of $\beta$-amyrin synthase (CabAS), a key enzyme in the biosynthesis of triterpene saponins, and the downregulation of cycloartenol synthase gene $(\mathrm{CaCAS})$. Furthermore, Suzuki et al. [59] reported an accumulation of saponins (triterpene aglycone) derived from $\beta$-amyrin, a product of the cyclization of (S)-2,3-epoxysqualene, and a significant reduction in $C A S$ transcript levels following MeJA-elicitation of Medicago truncatula. MeJA seems to have a clear effect on triterpenoids accumulation and cycloartenol synthase downregulation in higher plants.

Transposed to C. reinhardtii, these results could suggest that the branching pathway uses $(S)$ 2,3-epoxysqualene as substrate.

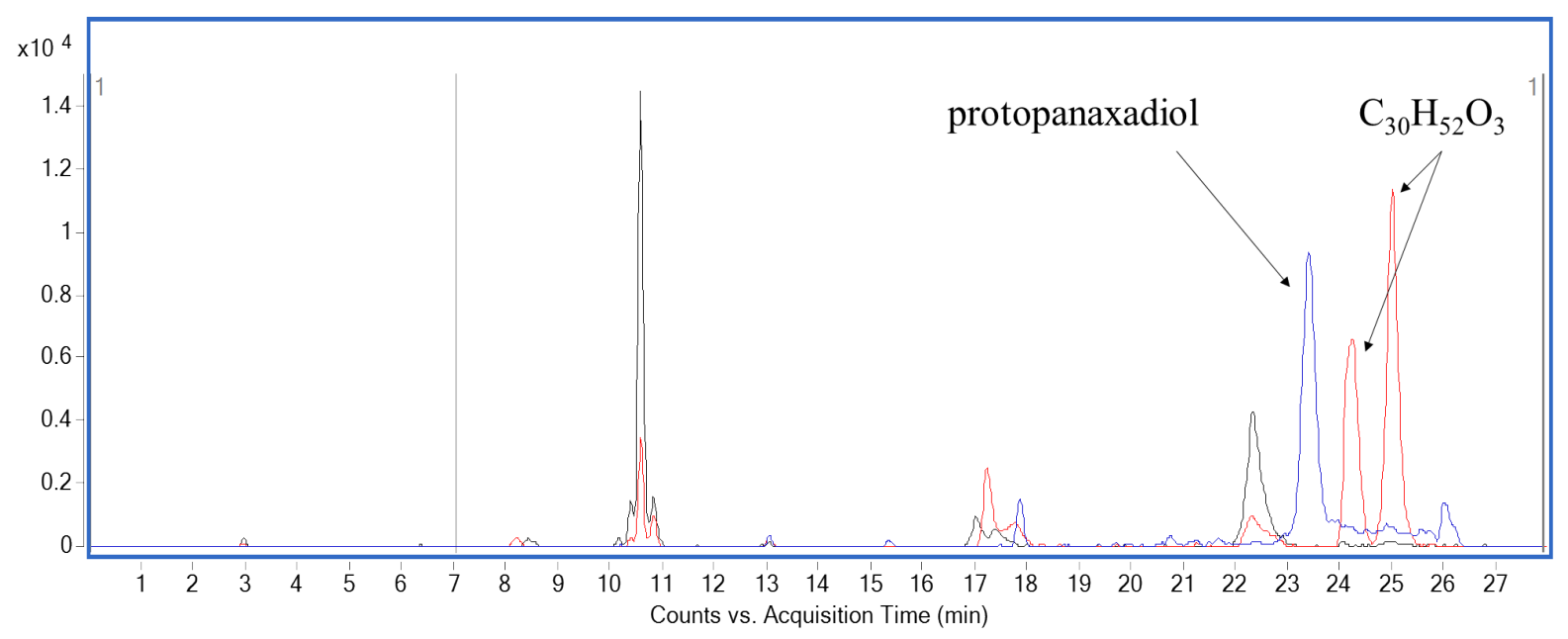

Figure 5. Detection of uncharacterised triterpenoid-based molecules in MeJA-treated

cells. Overlay of LC-MS chromatograms showing the accumulation of two triterpenoid-based 
molecules of same formula $\left(\mathrm{C}_{30} \mathrm{H}_{52} \mathrm{O}_{3}\right)$ in the $C$. reinhardtii cells treated with $1 \mathrm{mM}$ of MeJA (red) compared to the untreated cells (black) at 48 hours and the protopanaxadiol standard (blue). Data from one representative sample out of 3 biological replicates.

\subsection{Effect of growth conditions on isoprenoid metabolic flux}

Among environmental factors, light appears to have the most profound effect on the control of MEP-pathway flux [48]. In A. thaliana, light induces the accumulation of transcripts from the MEP-pathway genes and genes encoding enzymes of downstream pathways, such as carotenoid and chlorophyll biosynthesis [48]. Furthermore, the expression of AtDXS and AtHDR follows a circadian pattern, with levels of transcripts increasing and decreasing at day and night-time respectively [48]. In C. reinhardtii, the production of an heterologous diterpenoid $(13 \mathrm{R}(+)$ manoyl oxide) in the chloroplast was higher in photoautotrophic conditions $\left(\mathrm{CO}_{2}\right.$ as sole carbon source) in day:night illumination cycles than in continuous light [12]. The production of the sesquiterpene biodiesel precursor (E)- $\alpha$-bisabolene in the cytosol also showed to benefit from light:dark cycles, but mixotrophy (with acetate) yielded three times more bisabolene than autotrophy [13]. Environmental factors seem to affect the production of terpenoids depending on their localization within the cell, with the production of diterpenes in chloroplast being affected by light, while the production of sesquiterpenes in the cytosol is influenced by the carbon source. Lauersen et al. [9] observed that the abundance of FPP varies in C. reinhardtii depending on the carbon-regime, in this case acetate or $\mathrm{CO}_{2}$. Therefore, the production of native triterpenoids in C. reinhardtii is likely to be affected, to some extend, by the growth conditions. The transcriptomic datasets available on Phytozome (https://phytozome.jgi.doe.gov) showed that the target genes investigated in this study are differently regulated under different growth conditions (Supplementary Table A2), with some genes showing higher variations than others. Unfortunately, we cannot directly relate these 
regulations to our findings because (i) qPCR data and FPKM values are not directly comparable and (ii) most of datasets on Phytozome lack precise information about experimental conditions. The current study was conducted in mixotrophy (acetate) at constant low-light (up to $50 \mu \mathrm{mol}$ photon $\mathrm{m}^{-2} \mathrm{~s}^{-1}$ ). Some could argue that due to the difference in cell density between the control and the treatment after addition of MeJA, the growth conditions in the control and the treatment are slightly different (e.g. light exposure per cell) and could therefore influence the differences observed in metabolites concentrations. To address this question, future works will investigate the production of triterpenoids when the cells are exposed to high-light (over $300 \mu \mathrm{mol}$ photon $\mathrm{m}^{-2} \mathrm{~s}^{-1}$ ) or under photoautotrophic conditions and compare to the concentrations obtained under MeJA-elicitation. Ultimately, photoautotrophy (i.e. using light and $\mathrm{CO}_{2}$ as sole inputs) is the preferred condition for commercial production of terpenoid in a sustainable manner.

Finally, as a future perspective, it would be interesting to assess the productivity of $C$. reinhardtii strains engineered to produce each sesqui-, di-, and tri-terpenoids upon MeJA treatment. While strains producing heterologous sesqui- and di-terpenoids are already available $[9,12]$, C. reinhardtii strains producing heterologous triterpenoids could be created as shown in P. tricornutum [10].

\section{CONCLUSIONS}

This study showed that a 48 h-treatment of $C$. reinhardtii cells with $1 \mathrm{mM}$ of MeJA arrested the growth and significantly impaired the photosynthetic activity, while up-regulating the MEP pathway leading to the accumulation of the triterpenoids precursors farnesyl pyrophosphate, squalene and $(S)$-2,3-epoxysqualene. This increase in $(S)$-2,3-epoxysqualene 
was associated with a decrease in cycloartenol and main sterols of $C$. reinhardtii. Coupling metabolite profiling of elicitor-treated microalgae cells with gene expression analysis lead to new understandings in the regulation of isoprenoids and triterpenoids. This study also brought new insights in MeJA signalling, which is central in plant sciences. We suggested that the signalling mechanisms evolved independently, since C. reinhardtii seems to lack orthologs of key genes involved in MeJA signalling in plants. We provided evidence of the accumulation of a novel, likely specialised and uncharacterised triterpenoid secondary metabolite, and hypothesized the presence of a specialised pathway branching just upstream of cycloartenol. Further research is necessary and currently ongoning in our laboratory to identify and characterise metabolites and enzymes involved in this hypothetical metabolic branching in the triterpenoid metabolism of $C$. reinhardtii. This work represents one of the first efforts aimed at elucidating the regulation of terpenoid metabolism in C. reinhardtii, which is the most common model organism for algal biology and biotechnology. The knowledge generated by this work sets the basis for more detailed gene discovery experiments that will guide metabolic engineering and synthetic biology approaches for the heterologous production of terpenoids in algae.

\section{CONFLICT OF INTEREST}

The authors declare no conflict of interest.

\section{ACKNOWLEDGEMENTS}

This work was supported by funding from the Climate Change Cluster (C3) of the University of Technology Sydney (UTS, Australia). MF is supported by a CSIRO Synthetic Biology Future Science Platform Fellowship, co-funded by UTS and CSIRO (Australia). The authors would like to thank Associate Professor Claudia Vickers (The University of 

metabolites analysis.

\title{
AUTHOR'S CONTRIBUTIONS
}

A.S.C. and M.F. conceived and designed the study; A.S.C. and M.F. performed the research; U.K. acquired and analysed the chemistry data; J.A. extracted the RNA; A.S.C. and M.P. analysed qPCR data and performed statistical analysis; P.J.R. funded the research; A.S.C wrote the manuscript with inputs from M.F., U.K., J.A., M.P. and P.J.R.

\section{SUPPLEMENTARY MATERIAL}

\section{The BLASTp analysis was run against Phytozome using the following sequences as}

\author{
query:
}

\begin{abstract}
$>$ AT2G39940.1 [COI1]
MEDPDIKRCKLSCVATVDDVIEQVMTYITDPKDRDSASLVCRRWFKIDSETREHVTMALCYTATPDRLSRRFPNLRSLKLKGKPRA AMFNLIPENWGGYVTPWVTEISNNLRQLKSVHFRRMIVSDLDLDRLAKARADDLETLKLDKCSGFTTDGLLSIVTHCRKIKTLLME ESSFSEKDGKWLHELAQHNTSLEVLNFYMTEFAKISPKDLETIARNCRSLVSVKVGDFEILELVGFFKAAANLEEFCGGSLNEDIGM PEKYMNLVFPRKLCRLGLSYMGPNEMPILFPFAAQIRKLDLLYALLETEDHCTLIQKCPNLEVLETRNVIGDRGLEVLAQYCKQLK RLRIERGADEQGMEDEEGLVSQRGLIALAQGCQELEYMAVYVSDITNESLESIGTYLKNLCDFRLVLLDREERITDLPLDNGVRSLLI GCKKLRRFAFYLRQGGLTDLGLSYIGQYSPNVRWMLLGYVGESDEGLMEFSRGCPNLQKLEMRGCCFSERAIAAAVTKLPSLRYL WVQGYRASMTGQDLMQMARPYWNIELIPSRRVPEVNQQGEIREMEHPAHILAYYSLAGQRTDCPTTVRVLKEPI

$>$ AT1G19180.1 [JAZ1]

MSSSMECSEFVGSRRFTGKKPSFSQTCSRLSQYLKENGSFGDLSLGMACKPDVNGTLGNSRQPTTTMSLFPCEASNMDSMVQDVK PTNLFPRQPSFSSSSSSLPKEDVLKMTQTTRSVKPESQTAPLTIFYAGQVIVFNDFSAEKAKEVINLASKGTANSLAKNQTDIRSNIATI ANQVPHPRKTTTQEPIQSSPTPLTELPIARRASLHRFLEKRKDRVTSKAPYQLCDPAKASSNPQTTGNMSWLGLAAEI

$>$ At1g74950 [JAZ2]

MSSFSAECWDFSGRKPSFSQTCTRLSRYLKEKGSFGDLSLGMTCKPDVNGGSRQPTMMNLFPCEASGMDSSAGQEDIKPKTMFPR QSSFSSSSSSGTKEDVQMIKETTKSVKPESQSAPLTIFYGGRVMVFDDFSAEKAKEVIDLANKGSAKSFTCFTAEVNNNHSAYSQKEI ASSPNPVCSPAKTAAQEPIQPNPASLACELPIARRASLHRFLEKRKDRITSKAPYQIDGSAEASSKPTNPAWLSSR

$>$ AT3G17860 [JAZ3]

MERDFLGLGSKNSPITVKEETSESSRDSAPNRGMNWSFSNKVSASSSQFLSFRPTQEDRHRKSGNYHLPHSGSFMPSSVADVYDSTR KAPYSSVQGVRMFPNSNQHEETNAVSMSMPGFQSHHYAPGGRSFMNNNNNSQPLVGVPIMAPPISILPPPGSIVGTTDIRSSSKPIGS PAQLTIFYAGSVCVYDDISPEKAKAIMLLAGNGSSMPQVFSPPQTHQQVVHHTRASVDSSAMPPSFMPTISYLSPEAGSSTNGLGAT KATRGLTSTYHNNQANGSNINCPVPVSCSTNVMAPTVALPLARKASLARFLEKRKERVTSVSPYCLDKKSSTDCRRSMSECISSSLS SAT

$>$ At1g72450 [JAZ6]

MSTGQAPEKSNFSQRCSLLSRYLKEKGSFGNINMGLARKSDLELAGKFDLKGQQNVIKKVETSETRPFKLIQKFSIGEASTSTEDKAI YIDLSEPAKVAPESGNSQLTIFFGGKVMVFNEFPEDKAKEIMEVAKEANHVAVDSKNSQSHMNLDKSNVVIPDLNEPTSSGNNEDQ ETGQQHQVVERIARRASLHRFFAKRKDRAVARAPYQVNQHGSHLPPKPEMVAPSIKSGQSSQHIATPPKPKAHNHMPMEVDKKEG QSSKNLELKL
\end{abstract}


MSKATIELDFLGLEKKQTNNAPKPKFQKFLDRRRSFRDIQGAISKIDPEIIKSLLASTGNNSDSSAKSRSVPSTPREDQPQIPISPVHASL ARSSTELVSGTVPMTIFYNGSVSVFQVSRNKAGEIMKVANEAASKKDESSMETDLSVILPTTLRPKLFGQNLEGDLPIARRKSLQRF LEKRKERLVSTSPYYPTSA

$>$ AT1G70700 [JAZ9]

MERDFLGLSDKQYLSNNVKHEVNDDAVEERGLSTKAAREWGKSKVFATSSFMPSSDFQEAKAFPGAYQWGSVSAANVFRRCQFG GAFQNATPLLLGGSVPLPTHPSLVPRVASSGSSPQLTIFYGGTISVFNDISPDKAQAIMLCAGNGLKGETGDSKPVREAERMYGKQIH NTAATSSSSATHTDNFSRCRDTPVAATNAMSMIESFNAAPRNMIPSVPQARKASLARFLEKRKERLMSAMPYKKMLLDLSTGESSG MNYSSTSPT

\section{$>$ At1g32640 [MYC2]}

MTDYRLQPTMNLWTTDDNASMMEAFMSSSDISTLWPPASTTTTTATTETTPTPAMEIPAQAGFNQETLQQRLQALIEGTHEGWTY AIFWQPSYDFSGASVLGWGDGYYKGEEDKANPRRRSSSPPFSTPADQEYRKKVLRELNSLISGGVAPSDDAVDEEVTDTEWFFLVS MTQSFACGAGLAGKAFATGNAVWVSGSDQLSGSGCERAKQGGVFGMHTIACIPSANGVVEVGSTEPIRQSSDLINKVRILFNFDGG AGDLSGLNWNLDPDQGENDPSMWINDPIGTPGSNEPGNGAPSSSSQLFSKSIQFENGSSSTITENPNLDPTPSPVHSQTQNPKFNNTF SRELNFSTSSSTLVKPRSGEILNFGDEGKRSSGNPDPSSYSGQTQFENKRKRSMVLNEDKVLSFGDKTAGESDHSDLEASVVKEVAV EKRPKKRGRKPANGREEPLNHVEAERQRREKLNQRFYALRAVVPNVSKMDKASLLGDAIAYINELKSKVVKTESEKLQIKNQLEE VKLELAGRKASASGGDMSSSCSSIKPVGMEIEVKIIGWDAMIRVESSKRNHPAARLMSALMDLELEVNHASMSVVNDLMIQQATV KMGFRIYTQEQLRASLISKIG

\section{$>$ AT4G02570 [CUL1]}

MERKTIDLEQGWDYMQTGITKLKRILEGLNEPAFDSEQYMMLYTTIYNMCTQKPPHDYSQQLYDKYREAFEEYINSTVLPALREK HDEFMLRELFKRWSNHKVMVRWLSRFFYYLDRYFIARRSLPPLNEVGLTCFRDLVYNELHSKVKQAVIALVDKEREGEQIDRALL KNVLDIYVEIGMGQMERYEEDFESFMLQDTSSYYSRKASSWIQEDSCPDYMLKSEECLKKERERVAHYLHSSSEPKLVEKVQHELL VVFASQLLEKEHSGCRALLRDDKVDDLSRMYRLYHKILRGLEPVANIFKQHVTAEGNALVQQAEDTATNQVANTASVQEQVLIRK VIELHDKYMVYVTECFQNHTLFHKALKEAFEIFCNKTVAGSSSAELLATFCDNILKKGGSEKLSDEAIEDTLEKVVKLLAYISDKDL FAEFYRKKLARRLLFDRSANDDHERSILTKLKQQCGGQFTSKMEGMVTDLTLARENQNSFEDYLGSNPAANPGIDLTVTVLTTGF WPSYKSFDINLPSEMIKCVEVFKGFYETKTKHRKLTWIYSLGTCHINGKFDQKAIELIVSTYQAAVLLLFNTTDKLSYTEILAQLNLS HEDLVRLLHSLSCAKYKILLKEPNTKTVSQNDAFEFNSKFTDRMRRIKIPLPPVDERKKVVEDVDKDRRYAIDAAIVRIMKSRKVLG HQQLVSECVEQLSRMFKPDIKAIKKRMEDLITRDYLERDKENPNMFRYLA

Table A1. Analyse of variance using GraphPad Prism 5.0 software to test the dissimilarities in quantum yield, cell density, metabolites concentrations and differential expression of key metabolic genes in control and MeJA-treated cells of Chlamydomonas reinhardtii. Df = degrees of freedom; $\mathrm{MS}=$ mean sum of squares. Bold face indicates statistical significance $(\mathrm{P}$ $<0.05)$.

A. Two-way ANOVA and post-hoc Tukey's HSD test results for the quantum yield data.

\begin{tabular}{lrrrr}
\hline Source of Variation & Df & MS & F & P value \\
\hline Interaction & $\mathbf{6}$ & $\mathbf{0 . 0 0 7 0 0 7}$ & $\mathbf{5 . 6 2 3}$ & $\mathbf{0 . 0 0 2 6}$ \\
\hline Time & 2 & 0.003751 & 3.01 & 0.0777 \\
\hline Treatment & 3 & 0.006066 & 1.189 & 0.3736 \\
\hline
\end{tabular}

Tukey's multiple comparisons test

\begin{tabular}{lrrrr}
\hline & \multicolumn{1}{l}{ Mean Diff. } & Significant? & Summary & Adjusted P Value \\
\hline 0 hour & & & & ns \\
\hline $0 \mathrm{mM}$ vs. $0.05 \mathrm{mM}$ & -0.01467 & No & ns & 0.9840 \\
\hline $0 \mathrm{mM}$ vs. $0.5 \mathrm{mM}$ & 0.002333 & No & ns & 0.9999 \\
\hline $0 \mathrm{mM}$ vs. $1 \mathrm{mM}$ & 0.011 & No & ns & 0.9756 \\
\hline $0.05 \mathrm{mM}$ vs. $0.5 \mathrm{mM}$ & 0.017 & No & $\mathrm{ns}$ & 0.9231 \\
\hline $0.05 \mathrm{mM}$ vs. $1 \mathrm{mM}$ & 0.02567 & No & ns & 0.9966 \\
\hline $0.5 \mathrm{mM}$ vs. $1 \mathrm{mM}$ & 0.008667 & No & & \\
\hline $\mathbf{1 2}$ hours & & & & \\
\hline
\end{tabular}




\begin{tabular}{|c|c|c|c|c|c|}
\hline $0 \mathrm{mM}$ vs. $0.05 \mathrm{mM}$ & -0.01467 & No & \multicolumn{2}{|c|}{ ns } & 0.9840 \\
\hline $0 \mathrm{mM}$ vs. $0.5 \mathrm{mM}$ & -0.02533 & No & \multicolumn{2}{|c|}{ ns } & 0.9258 \\
\hline $0 \mathrm{mM}$ vs. $1 \mathrm{mM}$ & -0.03667 & No & \multicolumn{2}{|c|}{ ns } & 0.8088 \\
\hline $0.05 \mathrm{mM}$ vs. $0.5 \mathrm{mM}$ & -0.01067 & No & \multicolumn{2}{|c|}{ ns } & 0.9937 \\
\hline $0.05 \mathrm{mM}$ vs. $1 \mathrm{mM}$ & -0.022 & No & \multicolumn{2}{|c|}{ ns } & 0.9495 \\
\hline $0.5 \mathrm{mM}$ vs. $1 \mathrm{mM}$ & -0.01133 & No & \multicolumn{2}{|c|}{ ns } & 0.9925 \\
\hline \multicolumn{6}{|l|}{48 hours } \\
\hline $0 \mathrm{mM}$ vs. $0.05 \mathrm{mM}$ & & -0.01633 & No & ns & 0.9782 \\
\hline $0 \mathrm{mM}$ vs. $0.5 \mathrm{mM}$ & & -0.02033 & No & $\mathrm{ns}$ & 0.9595 \\
\hline $0 \mathrm{mM}$ vs. $1 \mathrm{mM}$ & & 0.146 & Yes & $* *$ & 0.0082 \\
\hline $0.05 \mathrm{mM}$ vs. $0.5 \mathrm{mM}$ & & -0.004 & No & ns & 0.9997 \\
\hline $0.05 \mathrm{mM}$ vs. $1 \mathrm{mM}$ & & 0.1623 & Yes & $* *$ & 0.0031 \\
\hline 0.5 mM vs. 1 mM & & 0.1663 & Yes & $* *$ & 0.0025 \\
\hline
\end{tabular}

B. Two-way ANOVA and post-hoc Tukey's HSD test results for the cell density data.

\begin{tabular}{lrrrr}
\hline Source of Variation & Df & MS & F & P value \\
\hline Interaction & $\mathbf{6}$ & $\mathbf{1 4 5 5 2 3 4 7 8 7 0 3 7}$ & $\mathbf{7 . 1 6 1}$ & $\mathbf{0 . 0 0 0 8}$ \\
\hline Time & $\mathbf{2}$ & $\mathbf{1 5 2 3 8 2 4 3 7 5 0 0 0 0}$ & $\mathbf{7 4 . 9 9}$ & $<\mathbf{0 . 0 0 0 1}$ \\
\hline Treatment & $\mathbf{3}$ & $\mathbf{9 2 3 2 3 0 9 2 5 9 2 6}$ & $\mathbf{8 . 0 5 7}$ & $\mathbf{0 . 0 0 8 4}$ \\
\hline
\end{tabular}

Tukey's multiple comparisons test

\begin{tabular}{|c|c|c|c|c|}
\hline & Mean Diff. & Significant? & Summary & Adjusted P Value \\
\hline \multicolumn{5}{|l|}{ O hour } \\
\hline $0 \mathrm{mM}$ vs. $0.05 \mathrm{mM}$ & 283333 & No & ns & 0.8384 \\
\hline $0 \mathrm{mM}$ vs. $0.5 \mathrm{mM}$ & -133333 & No & ns & 0.9791 \\
\hline $0 \mathrm{mM}$ vs. $1 \mathrm{mM}$ & -304333 & No & ns & 0.8078 \\
\hline $0.05 \mathrm{mM}$ vs. $0.5 \mathrm{mM}$ & -416667 & No & ns & 0.6178 \\
\hline $0.05 \mathrm{mM}$ vs. $1 \mathrm{mM}$ & -587667 & No & ns & 0.3322 \\
\hline $0.5 \mathrm{mM}$ vs. $1 \mathrm{mM}$ & -171000 & No & ns & 0.9577 \\
\hline \multicolumn{5}{|l|}{12 hours } \\
\hline $0 \mathrm{mM}$ vs. $0.05 \mathrm{mM}$ & 145333 & No & ns & 0.9733 \\
\hline $0 \mathrm{mM}$ vs. $0.5 \mathrm{mM}$ & -62000 & No & ns & 0.9978 \\
\hline $0 \mathrm{mM}$ vs. $1 \mathrm{mM}$ & 180333 & No & ns & 0.9509 \\
\hline $0.05 \mathrm{mM}$ vs. $0.5 \mathrm{mM}$ & -207333 & No & ns & 0.9281 \\
\hline $0.05 \mathrm{mM}$ vs. $1 \mathrm{mM}$ & 35000 & No & ns & 0.9996 \\
\hline $0.5 \mathrm{mM}$ vs. $1 \mathrm{mM}$ & 242333 & No & ns & 0.8913 \\
\hline \multicolumn{5}{|l|}{48 hours } \\
\hline $0 \mathrm{mM}$ vs. $0.05 \mathrm{mM}$ & -210000 & No & ns & 0.9256 \\
\hline $0 \mathrm{mM}$ vs. $0.5 \mathrm{mM}$ & 530000 & No & ns & 0.4206 \\
\hline 0 mM vs. 1 mM & 2210000 & Yes & $* * * *$ & $<0.0001$ \\
\hline $0.05 \mathrm{mM}$ vs. $0.5 \mathrm{mM}$ & 740000 & No & ns & 0.1591 \\
\hline 0.05 mM vs. $1 \mathrm{mM}$ & 2420000 & Yes & $* * * *$ & $<0.0001$ \\
\hline 0.5 mM vs. 1 mM & 1680000 & Yes & $* * *$ & 0.0003 \\
\hline
\end{tabular}

C. One-way ANOVA results for gene expression data at 48 hours of treatment with MeJA.

\begin{tabular}{lrrrr}
\hline Genes & DF & MS & F & P value \\
\hline$D X S$ & 3 & 12.04 & 2.554 & 0.1285 \\
\hline $\boldsymbol{D X} \boldsymbol{R}$ & $\mathbf{3}$ & $\mathbf{1 2 2 . 1}$ & $\mathbf{7 . 5}$ & $\mathbf{0 . 0 1 0 4}$ \\
\hline$C M K$ & 3 & 3.652 & 3.821 & 0.0575 \\
\hline $\boldsymbol{M D S}$ & $\mathbf{3}$ & $\mathbf{2 0 4 . 8}$ & $\mathbf{6 7 . 3}$ & $<\mathbf{0 . 0 0 0 1}$ \\
\hline
\end{tabular}




\begin{tabular}{llrrr}
\hline$I D I$ & 3 & 58.14 & 1.388 & 0.3151 \\
\hline$F P P S$ & 3 & 1.835 & 0.1236 & 0.9435 \\
\hline $\boldsymbol{S Q E}$ & $\mathbf{3}$ & $\mathbf{8 2 . 4 8}$ & $\mathbf{4 . 2 5 3}$ & $\mathbf{0 . 0 4 5 1}$ \\
\hline$C A S$ & 3 & 2.999 & 2.634 & 0.1216 \\
\hline$C Y P 51$ & 3 & 5.834 & 0.664 & 0.5972 \\
\hline$E R G 4 / 24$ & 3 & 14.3 & 0.7222 & 0.5664 \\
\hline
\end{tabular}

Dunnett's multiple comparisons test (comparing the mean of each treatment with the mean of the control)

\begin{tabular}{|c|c|c|c|c|}
\hline Genes & Mean Diff. & Significant? & Summary & Adjusted P Value \\
\hline \multicolumn{5}{|l|}{$D X S$} \\
\hline $0 \mathrm{mM}$ vs. $0.05 \mathrm{mM}$ & -0.02483 & No & ns & $>0.9999$ \\
\hline $0 \mathrm{mM}$ vs. $0.5 \mathrm{mM}$ & 0.01389 & No & ns & $>0.9999$ \\
\hline $0 \mathrm{mM}$ vs. $1 \mathrm{mM}$ & -4.01 & No & ns & 0.1249 \\
\hline \multicolumn{5}{|l|}{$D X R$} \\
\hline $0 \mathrm{mM}$ vs. $0.05 \mathrm{mM}$ & 0.6167 & No & ns & 0.9950 \\
\hline $0 \mathrm{mM}$ vs. $0.5 \mathrm{mM}$ & 1.618 & No & ns & 0.9263 \\
\hline 0 mM vs. 1 mM & -11.94 & Yes & * & 0.0169 \\
\hline \multicolumn{5}{|l|}{ CMK } \\
\hline $0 \mathrm{mM}$ vs. $0.05 \mathrm{mM}$ & 0.4115 & No & ns & 0.9166 \\
\hline $0 \mathrm{mM}$ vs. $0.5 \mathrm{mM}$ & -0.2937 & No & ns & 0.9659 \\
\hline $0 \mathrm{mM}$ vs. $1 \mathrm{mM}$ & -2.09 & No & ns & 0.0737 \\
\hline \multicolumn{5}{|l|}{ MDS } \\
\hline $0 \mathrm{mM}$ vs. $0.05 \mathrm{mM}$ & -0.4692 & No & ns & 0.9749 \\
\hline $0 \mathrm{mM}$ vs. $0.5 \mathrm{mM}$ & -0.7178 & No & ns & 0.9212 \\
\hline 0 mM vs. 1 mM & -16.91 & Yes & $* * * *$ & $<0.0001$ \\
\hline \multicolumn{5}{|l|}{ IDI } \\
\hline $0 \mathrm{mM}$ vs. $0.05 \mathrm{mM}$ & 0.0567 & No & ns & $>0.9999$ \\
\hline $0 \mathrm{mM}$ vs. $0.5 \mathrm{mM}$ & 0.6673 & No & ns & 0.9985 \\
\hline $0 \mathrm{mM}$ vs. $1 \mathrm{mM}$ & -8.543 & No & ns & 0.3114 \\
\hline \multicolumn{5}{|l|}{ FPPS } \\
\hline $0 \mathrm{mM}$ vs. $0.05 \mathrm{mM}$ & 1.362 & No & ns & 0.9469 \\
\hline $0 \mathrm{mM}$ vs. $0.5 \mathrm{mM}$ & 0.161 & No & ns & $>0.9999$ \\
\hline $0 \mathrm{mM}$ vs. $1 \mathrm{mM}$ & 1.492 & No & ns & 0.9327 \\
\hline \multicolumn{5}{|l|}{$S Q E$} \\
\hline $0 \mathrm{mM}$ vs. $0.05 \mathrm{mM}$ & -0.9324 & No & ns & 0.9872 \\
\hline $0 \mathrm{mM}$ vs. $0.5 \mathrm{mM}$ & -0.7546 & No & ns & 0.9931 \\
\hline 0 mM vs. 1 mM & -11.02 & Yes & $*$ & 0.0381 \\
\hline \multicolumn{5}{|l|}{ CAS } \\
\hline $0 \mathrm{mM}$ vs. $0.05 \mathrm{mM}$ & 0.2353 & No & ns & 0.9857 \\
\hline $0 \mathrm{mM}$ vs. $0.5 \mathrm{mM}$ & -0.06539 & No & ns & 0.9996 \\
\hline $0 \mathrm{mM}$ vs. $1 \mathrm{mM}$ & -1.926 & No & ns & 0.1346 \\
\hline \multicolumn{5}{|l|}{ CYP51 } \\
\hline $0 \mathrm{mM}$ vs. $0.05 \mathrm{mM}$ & 0.6466 & No & ns & 0.9861 \\
\hline $0 \mathrm{mM}$ vs. $0.5 \mathrm{mM}$ & -0.151 & No & ns & 0.9999 \\
\hline $0 \mathrm{mM}$ vs. $1 \mathrm{mM}$ & -2.537 & No & ns & 0.6137 \\
\hline \multicolumn{5}{|l|}{$E R G 4 / 24$} \\
\hline $0 \mathrm{mM}$ vs. $0.05 \mathrm{mM}$ & 0.9009 & No & ns & 0.9888 \\
\hline $0 \mathrm{mM}$ vs. $0.5 \mathrm{mM}$ & 0.1606 & No & ns & $>0.9999$ \\
\hline $0 \mathrm{mM}$ vs. $1 \mathrm{mM}$ & -3.942 & No & ns & 0.5909 \\
\hline
\end{tabular}


D. Two-tailed unpaired $t$-test results testing dissimilarities in metabolites concentrations between control and treated cells (1mM MeJA) at 48 hours of treatment.

\begin{tabular}{lll}
\hline Metabolite & $\mathrm{t}(\mathrm{df})$ & P value \\
\hline MEP & $\mathbf{t}(\mathbf{4})=\mathbf{3 . 0 6 9}$ & $\mathbf{0 . 0 3 7 3}$ \\
\hline MEcPP & $\mathbf{t}(\mathbf{4})=\mathbf{4 . 5 0 6}$ & $\mathbf{0 . 0 1 0 8}$ \\
\hline GGPP & $\mathbf{t}(\mathbf{4})=\mathbf{3 . 8 8 1}$ & $\mathbf{0 . 0 1 7 8}$ \\
\hline FPP & $\mathbf{t}(\mathbf{4})=\mathbf{1 2 . 9 9}$ & $\mathbf{0 . 0 0 0 2}$ \\
\hline Squalene & $\mathbf{t}(\mathbf{4})=\mathbf{6 . 1 4 4}$ & $\mathbf{0 . 0 0 3 6}$ \\
\hline cycloartenol & $\mathrm{t}(4)=2.502$ & 0.0666 \\
\hline ergosterol & $\mathbf{t}(\mathbf{4})=\mathbf{6 . 4 1 5}$ & $\mathbf{0 . 0 0 3 0}$ \\
\hline 7-dehydroporiferasterol & $\mathbf{t}(\mathbf{4})=\mathbf{7 . 3 0 5}$ & $\mathbf{0 . 0 0 1 9}$ \\
\hline
\end{tabular}

Table A2. FPKM values for genes of interest as reported in Phytozome.

\begin{tabular}{|c|c|c|c|c|c|c|c|c|c|c|c|}
\hline $\begin{array}{l}\text { Experiment } \\
\text { group }\end{array}$ & Experiment Name & DXS & DXR & СМК & MDS & IDI & FPPS & SQE & CAS & CYP51 & $\begin{array}{l}\text { ERG4 } \\
/ 24\end{array}$ \\
\hline \multirow[t]{20}{*}{ Anaerobiosis } & $\begin{array}{l}\text { CC-124 Dark anoxic } \\
.5 \text { hour }\end{array}$ & 93.9 & 38.972 & 12.026 & 67.159 & 47.594 & 20.093 & 14.499 & 11.011 & 13.382 & 6.272 \\
\hline & $\begin{array}{l}\text { CC-124 Dark anoxic } 6 \\
\text { hours }\end{array}$ & 68.557 & 58.677 & 9.885 & 54.511 & 15.577 & 15.824 & 185.632 & 24.514 & 236.999 & 5.267 \\
\hline & CC-124 Light oxic & 97.465 & 64.004 & 22.566 & 65.998 & 15.837 & 33.691 & 22.323 & 15.77 & 40.129 & 10.693 \\
\hline & crr1 Dark oxic .5 hour & 108.694 & 40.884 & 7.106 & 45.291 & 23.251 & 11.596 & 12.99 & 7.518 & 8.624 & 4.938 \\
\hline & $\begin{array}{l}\text { crr1 Dark oxic } 6 \text { hours } \\
\text { (1) }\end{array}$ & 109.284 & 45.444 & 6.619 & 40.26 & 21.247 & 10.044 & 11.277 & 11.047 & 10.553 & 5.793 \\
\hline & $\begin{array}{l}\text { crr1 Dark oxic } 6 \text { hours } \\
\text { (2) }\end{array}$ & 90.498 & 37.926 & 7.312 & 31.419 & 18.384 & 11.096 & 10.371 & 8.948 & 12.24 & 6.392 \\
\hline & crr1 Light oxic (1) & 115.436 & 57.161 & 16.202 & 61.872 & 16.365 & 27.095 & 14.637 & 8.76 & 26.43 & 11.791 \\
\hline & crr1 Light oxic (2) & 125.261 & 63.474 & 16.536 & 67.366 & 19.297 & 20.589 & 15.021 & 8.507 & 23.114 & 10.663 \\
\hline & $\begin{array}{l}\text { crr1:CRR1 Dark } \\
\text { anoxic .5 hour (1) }\end{array}$ & 91.519 & 38.873 & 8.618 & 40.816 & 21.106 & 12.608 & 13.321 & 5.935 & 8.147 & 4.292 \\
\hline & $\begin{array}{l}\text { crr1:CRR1 Dark } \\
\text { anoxic } .5 \text { hour }(2)\end{array}$ & 74.324 & 30.533 & 8.085 & 36.031 & 19.009 & 13.51 & 13.239 & 6.741 & 13.426 & 6.787 \\
\hline & $\begin{array}{l}\text { crr1:CRR1 Dark } \\
\text { anoxic } 6 \text { hours (1) }\end{array}$ & 90.585 & 62.397 & 4.006 & 59.431 & 9.268 & 14.73 & 22.066 & 6.494 & 16.286 & 6.734 \\
\hline & $\begin{array}{l}\text { crr1:CRR1 Dark } \\
\text { anoxic } 6 \text { hours }(2)\end{array}$ & 96.468 & 43.308 & 5.717 & 40.786 & 18.089 & 10.131 & 54.256 & 13.736 & 37.194 & 4.145 \\
\hline & $\begin{array}{l}\text { crr1:CRR1 Light oxic } \\
\text { (1) }\end{array}$ & 91.236 & 52.824 & 14.882 & 66.517 & 16.409 & 23.368 & 15.501 & 8.984 & 25.058 & 11.994 \\
\hline & $\begin{array}{l}\text { crr1:CRR1 Light oxic } \\
\text { (2) }\end{array}$ & 108.981 & 62.09 & 16.924 & 63.15 & 15.619 & 19.019 & 15.177 & 8.285 & 22.41 & 9.683 \\
\hline & $\begin{array}{l}\text { crrldCys Dark anoxic } \\
.5 \text { hour (1) }\end{array}$ & 82.715 & 33.924 & 7.297 & 43.421 & 22.778 & 13.49 & 11.507 & 6.642 & 13.312 & 7.148 \\
\hline & $\begin{array}{l}\text { crrldCys Dark anoxic } \\
.5 \text { hour }(2)\end{array}$ & 81.715 & 32.186 & 8.977 & 40.994 & 22.47 & 16.343 & 10.853 & 6.88 & 15.394 & 7.041 \\
\hline & $\begin{array}{l}\text { crrldCys Dark anoxic } \\
6 \text { hours (1) }\end{array}$ & 93.594 & 42.759 & 11.415 & 52.198 & 18.916 & 13.399 & 13.058 & 9.604 & 23.857 & 7.238 \\
\hline & $\begin{array}{l}\text { crrldCys Dark anoxic } \\
6 \text { hours (2) }\end{array}$ & 95.519 & 50.635 & 11.108 & 68.242 & 18.103 & 15.003 & 13.846 & 10.797 & 36.318 & 7.753 \\
\hline & $\begin{array}{l}\text { crrldCys Light oxic } \\
\text { (1) }\end{array}$ & 106.146 & 56.946 & 16.078 & 78.432 & 23.632 & 23.289 & 16.036 & 9.863 & 27.252 & 15.554 \\
\hline & $\begin{array}{l}\text { crrldCys Light oxic } \\
(2)\end{array}$ & 102.972 & 53.802 & 17.731 & 70.258 & 21.39 & 28.184 & 15.175 & 9.498 & 30.78 & 15.104 \\
\hline \multirow[t]{5}{*}{ Bilin Signaling } & $\begin{array}{l}4 \mathrm{~A}+0 \mathrm{mM}, 0.5 \mathrm{~h} \text { white } \\
\text { light (1) }\end{array}$ & 254.607 & 85.813 & 9.855 & 117.231 & 96.502 & 45.399 & 80.269 & 38.73 & 84.341 & 50.41 \\
\hline & $\begin{array}{l}4 \mathrm{~A}+0 \mathrm{mM}, 0.5 \mathrm{~h} \text { white } \\
\text { light (2) }\end{array}$ & 249.82 & 84.871 & 8.264 & 114.255 & 94.83 & 45.608 & 84.512 & 40.579 & 85.569 & 51.184 \\
\hline & $4 \mathrm{~A}+0 \mathrm{mM}$,dark (1) & 107.473 & 46.216 & 10.984 & 29.458 & 11.427 & 28.109 & 18.051 & 10.908 & 34.65 & 8.184 \\
\hline & $4 \mathrm{~A}+0 \mathrm{mM}$,dark (2) & 102.505 & 43.87 & 8.576 & 27.505 & 10.902 & 25.693 & 17.005 & 10.532 & 31.249 & 6.257 \\
\hline & $\begin{array}{l}4 \mathrm{~A}+0.1 \mathrm{mM} \mathrm{BV} \\
\text { IXa, } 0.5 \mathrm{~h} \text { white light } \\
\text { (1) }\end{array}$ & 222.203 & 73.755 & 6.834 & 85.376 & 63.026 & 31.655 & 82.356 & 37.375 & 118.737 & 38.875 \\
\hline
\end{tabular}


$4 \mathrm{~A}+0.1 \mathrm{mM} \mathrm{BV}$

IXa, $0.5 \mathrm{~h}$ white light

(2)

$4 \mathrm{~A}+0.1 \mathrm{mM} \mathrm{BV}$

IXa,dark (1)

$4 \mathrm{~A}+0.1 \mathrm{mM} \mathrm{BV}$

IXa,dark (2)

hmox $10 \mathrm{mM}, 0.5 \mathrm{~h}$

white light (1)

hmox $10 \mathrm{mM}, 0.5 \mathrm{~h}$

white light (2)

hmox 10 mM,dark (1)

hmox 10 mM,dark (2)

hmox1 $0.1 \mathrm{mM}$ BV

IXa, $0.5 \mathrm{~h}$ white light

(1)

hmox1 $0.1 \mathrm{mM}$ BV

IXa, $0.5 \mathrm{~h}$ white light

(2)

hmox1 $0.1 \mathrm{mM} \mathrm{BV}$

IXa,dark (1)

hmox1 0.1 mM BV

IXa,dark (2)

Cu Deficiency WT-2137 Copper

Photoautotrophic

deficient (Minimal

media) 3

WT-2137 Copper

deficient (TAP) 5

WT-2137 Copper

deficient (TAP) 6

WT-2137 Copper

deficient (TAP) 7

WT-2137 Copper

sufficient (Minimal

media) 1

WT-2137 Copper

sufficient (Minimal

media) 3

WT-2137 Copper

deficient (Minimal

media) 1

WT-2137 Copper

deficient (TAP) 10

WT-2137_Copper

deficient (TAP) 8

WT-2137_Copper

deficient (TAP) 9

WT-2137_Copper

sufficient (TAP) 10

WT-2137 Copper

sufficient (TAP) 3

WT-2137 Copper

sufficient (TAP) 5

WT-2137_Copper

sufficient (TAP) 6

WT-2137 Copper

sufficient (TAP) 7

WT-2137_Copper

sufficient (TAP) 8

WT-2137 Copper

sufficient (TAP) 9

crr1-2 Copper

deficient (TAP) 3

crr1-2 Copper

deficient (TAP) 4

crr1:CRR1 Copper

deficient (TAP) 1

crr1:CRR1 Copper

deficient (TAP) 2

WT-2137 Fe replete

(Minimal media) 1

WT-2137 Fe replete

(Minimal media) 2 $\begin{array}{llllllllll}233.811 & 75.885 & 6.219 & 86.228 & 66.548 & 35.657 & 71.77 & 39.592 & 126.38 & 41.009\end{array}$

$\begin{array}{llllllllll}96.49 & 40.743 & 8.042 & 23.596 & 11.748 & 20.833 & 20.541 & 10.401 & 26.061 & 6.367\end{array}$

$\begin{array}{llllllllll}92.328 & 40.085 & 7.12 & 23.977 & 10.847 & 22.029 & 18.571 & 9.205 & 25.774 & 6.961\end{array}$

$\begin{array}{llllllllll}140.701 & 72.741 & 8.585 & 74.657 & 60.112 & 39.92 & 60.767 & 24.216 & 76.397 & 29.479\end{array}$

$\begin{array}{llllllllll}146.772 & 71.506 & 8.106 & 70.017 & 58.841 & 38.39 & 60.673 & 24.008 & 78.39 & 30.799\end{array}$

$\begin{array}{llllllllll}88.789 & 44.346 & 8.829 & 30.012 & 17.056 & 29.526 & 20.501 & 9.568 & 37.037 & 7.338\end{array}$

$\begin{array}{llllllllll}90.909 & 45.98 & 8.526 & 29.553 & 16.122 & 24.224 & 20.714 & 9.701 & 34.759 & 7.441\end{array}$

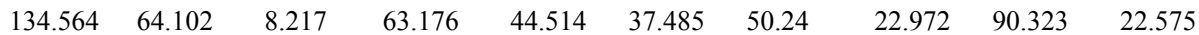

$\begin{array}{llllllllll}144.556 & 65.175 & 7.567 & 64.189 & 46.251 & 33.481 & 52.97 & 25.011 & 99.977 & 22.21\end{array}$

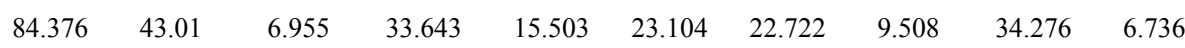

$\begin{array}{llllllllll}85.868 & 47.487 & 8.376 & 30.422 & 15.98 & 23.178 & 22.275 & 9.705 & 34.758 & 7.407\end{array}$

$\begin{array}{llllllllll}143.678 & 58.931 & 9.928 & 51.578 & 10.126 & 16.962 & 71.086 & 12.155 & 39.409 & 8.427\end{array}$

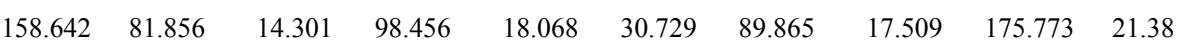

$\begin{array}{llllllllll}145.907 & 71.424 & 22.333 & 110.119 & 23.416 & 31.982 & 104.775 & 25.513 & 183.672 & 18.071\end{array}$

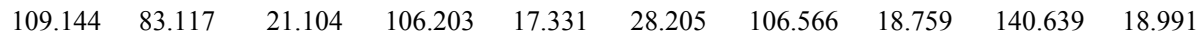

$\begin{array}{llllllllll}137.187 & 58.762 & 12.703 & 63.151 & 10.569 & 17.856 & 16.481 & 7.415 & 21.017 & 8.151\end{array}$

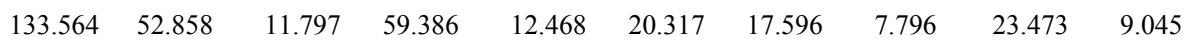

$\begin{array}{llllllllll}105.652 & 31.486 & 7.906 & 33.59 & 9.905 & 16.384 & 68.73 & 12.061 & 58.952 & 8.272\end{array}$

$\begin{array}{llllllllll}105.754 & 74.668 & 20.513 & 105.763 & 19.184 & 29.897 & 112.212 & 20.081 & 145.642 & 17.243\end{array}$

$\begin{array}{llllllllll}115.638 & 81.522 & 23.887 & 106.797 & 20.271 & 32.665 & 103.911 & 22.073 & 130.105 & 13.778\end{array}$

$\begin{array}{llllllllll}111.442 & 76.722 & 21.823 & 106.856 & 16.313 & 29.745 & 113.236 & 17.774 & 142.442 & 16.362\end{array}$

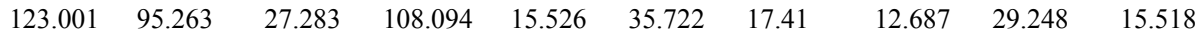

$\begin{array}{llllllllll}169.302 & 93.73 & 35.178 & 130.859 & 24.659 & 45.124 & 16.087 & 13.653 & 41.276 & 23.551\end{array}$

$\begin{array}{llllllllll}174.76 & 114.979 & 15.114 & 114.48 & 20.902 & 38.501 & 11.545 & 14.598 & 32.54 & 20.938\end{array}$

$\begin{array}{llllllllll}165.877 & 98.861 & 25.353 & 109.15 & 17.734 & 37.51 & 15.355 & 13.992 & 37.67 & 22.006\end{array}$

$\begin{array}{llllllllll}126.431 & 102.378 & 25.547 & 109.438 & 15.468 & 33.625 & 14.576 & 13.663 & 28.972 & 17.446\end{array}$

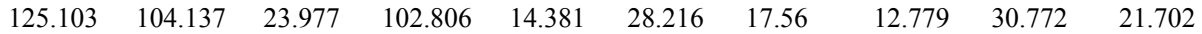

$\begin{array}{llllllllll}115.352 & 107.999 & 27.536 & 118.052 & 13.737 & 32.268 & 18.967 & 14.251 & 30.066 & 18.377\end{array}$

$\begin{array}{llllllllll}94.523 & 64.352 & 24.664 & 49.22 & 11.147 & 27.165 & 45.152 & 11.135 & 40.016 & 10.022\end{array}$

$\begin{array}{llllllllll}95.945 & 79.926 & 29.655 & 43.829 & 9.847 & 30.682 & 45.261 & 14.987 & 32.357 & 10.966\end{array}$

$\begin{array}{llllllllll}109.851 & 41.579 & 21.502 & 46.53 & 11.698 & 31.97 & 10.935 & 5.053 & 13.766 & 13.727\end{array}$

$\begin{array}{llllllllll}110.606 & 39.579 & 26.511 & 47.968 & 12.246 & 31.091 & 11.179 & 5.257 & 14.129 & 13.493\end{array}$

$\begin{array}{llllllllll}145.233 & 37.791 & 8.247 & 46.189 & 19.572 & 16.581 & 16.462 & 11.443 & 21.048 & 16.473\end{array}$

$\begin{array}{llllllllll}137.086 & 41.75 & 7.035 & 47.452 & 19.332 & 15.164 & 17.385 & 10.844 & 20.932 & 11.472\end{array}$ 
WT-2137 Fe replete (Minimal media) 3 WT-2137 Fe replete (Minimal media) 4 WT-2137 Fe replete (TAP) 1

WT-2137 Fe replete (TAP) 2

WT-2137 Fe-deficient (Minimal media) 1 WT-2137 Fe-deficient (Minimal media) 2 WT-2137 Fe-deficient (Minimal media) 3 WT-2137 Fe-deficient (Minimal media) 4 WT-2137 Fe-deficient (TAP) 1

WT-2137 Fe-deficient (TAP) 2

WT-2137 Fe-deficient

(TAP) 3

WT-2137 Fe-limited

(Minimal media) 1

WT-2137 Fe-limited

(Minimal media) 2

WT-2137 Fe-limited

(Minimal media) 3

WT-2137 Fe-limited

(Minimal media) 4

WT-2137 Fe-limited

(TAP) 1

WT-2137 Fe-limited

(TAP) 2

WT-2137 Fe-limited (TAP) 3

Early

Hetero.Ammonia

MidLog

Hetero.Nitrate

Hetero.Urea

Mixo.Ammonia

Mixo.Ammonia

Diurnal

Mixo.Ammonia Early

Mixo.Ammonia

MidLog

Mixo.HighLight Early

MidLog

Mixo.Nitrate

Mixo.Nitrate Diurnal

Mixo.Urea Diurnal

MixoUrea

Photo.Ammonia

Photo.Ammonia

Diurnal

Photo.Ammonia Early

Photo.Ammonia

MidLog

Photo.HighLight Early

Photo.HighLight

MidLog

Photo.Nitrate

Photo.Nitrate Diurnal $\begin{array}{llllllllll}140.476 & 45.822 & 4.46 & 50.931 & 23.303 & 15.271 & 15.794 & 12.436 & 19.223 & 12.975\end{array}$

$\begin{array}{llllllllll}137.085 & 45.063 & 4.462 & 49.25 & 23.586 & 14.255 & 19.391 & 12.241 & 17.89 & 12.72\end{array}$

$\begin{array}{llllllllll}101.912 & 27.588 & 14.528 & 42.023 & 29.716 & 35.699 & 16.893 & 10.835 & 26.952 & 20.222\end{array}$

$\begin{array}{llllllllll}90.594 & 31.243 & 9.96 & 44.283 & 32.188 & 33.899 & 14.85 & 9.857 & 30.391 & 18.221\end{array}$

$\begin{array}{llllllllll}135.963 & 35.12 & 4.289 & 47.059 & 23.264 & 17.852 & 16.735 & 10.543 & 18.662 & 13.503\end{array}$

$\begin{array}{llllllllll}134.279 & 37.964 & 6.091 & 39.706 & 20.272 & 16.241 & 21.087 & 10.419 & 17.871 & 11.304\end{array}$

$\begin{array}{llllllllll}129.846 & 37.993 & 6.632 & 47.797 & 21.414 & 19.705 & 12.162 & 10.567 & 21.08 & 12.97\end{array}$

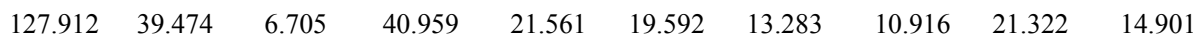

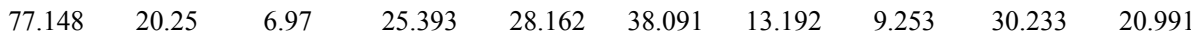

$\begin{array}{llllllllll}78.413 & 25.028 & 12.416 & 32.941 & 24.838 & 36.526 & 14.232 & 11.502 & 36.347 & 14.758\end{array}$

$\begin{array}{llllllllll}82.119 & 24.344 & 11.045 & 35.884 & 25.267 & 33.658 & 15.105 & 10.23 & 35.262 & 18.055\end{array}$

$\begin{array}{llllllllll}133.634 & 29.037 & 3.249 & 33.986 & 28.541 & 14.606 & 18.663 & 10.379 & 18.488 & 17.517\end{array}$

$\begin{array}{llllllllll}128.205 & 30.109 & 3.588 & 37.21 & 27.333 & 14.707 & 18.543 & 11.754 & 16.285 & 13.675\end{array}$

$\begin{array}{llllllllll}113.909 & 25.679 & 1.919 & 32.138 & 30.616 & 16.6 & 17.413 & 10.58 & 16.164 & 15.698\end{array}$

$\begin{array}{llllllllll}117.427 & 26.498 & 3.171 & 29.549 & 28.53 & 12.466 & 17.945 & 10.632 & 15.901 & 14.656\end{array}$

$\begin{array}{llllllllll}118.755 & 50.129 & 7.672 & 43.877 & 51.806 & 31.552 & 10.271 & 14.113 & 21.493 & 16.676\end{array}$

$\begin{array}{llllllllll}123.811 & 47.582 & 10.523 & 44.717 & 53.987 & 29.451 & 15.227 & 12.066 & 19.766 & 14.812\end{array}$

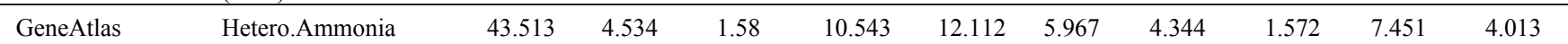

Hetero.Ammonia

$59.978 \quad 8.983$

$\begin{array}{lllll}7.929 & 37.815 & 6.268 & 10.725 \quad 3.484\end{array}$

$0.709 \quad 10.939$

4.351

$54.53 \quad 6.923$

4.323

19.756

$6.945 \quad 15.781 \quad 2.977$

1.375

14.681

7.081

$31.83 \quad 4.995$

7.933

13.626

$\begin{array}{lll}6.577 & 19.862 \quad 3.845\end{array}$

1.258

27.557

6.256

$7.312 \quad 1$

$83.619 \quad 21.501$

019

3.23

1.176

0.161

0.884

$127.897 \quad 38.39$

$72.552 \quad 14.7$

29.874

1.897

14.768

Mixo.HighLight

$80.766-19.486$

11.725

36.868

18.19

13.98

7.958

1.895

15.525
$55.154 \quad 9.203$

\section{7}

7

22.384

$111.685 \quad 36.675$

77.086

22.262

$85.253 \quad 14.252$

$128.549 \quad 30.839$

65.414

11.516

9.623

33.609

14.92

14.476

10.154

55.461

11.37

$15.742 \quad 35.74$

6.16

$23.61 \quad 92.096 \quad 3.216$

16.539

43.779

8.697

$30.434 \quad 7.562$

23.047

62.66

3.912

8.698

26.593

12.24

78.268

10.752

46.646

8.069

4.961

26.938

10.12

$18.678 \quad 9.621$

9.719

10.599

6.962

10.468

24.092

28.083

5.588

22.855
$64.219 \quad 2.482$
$121.535 \quad 31.5$

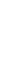




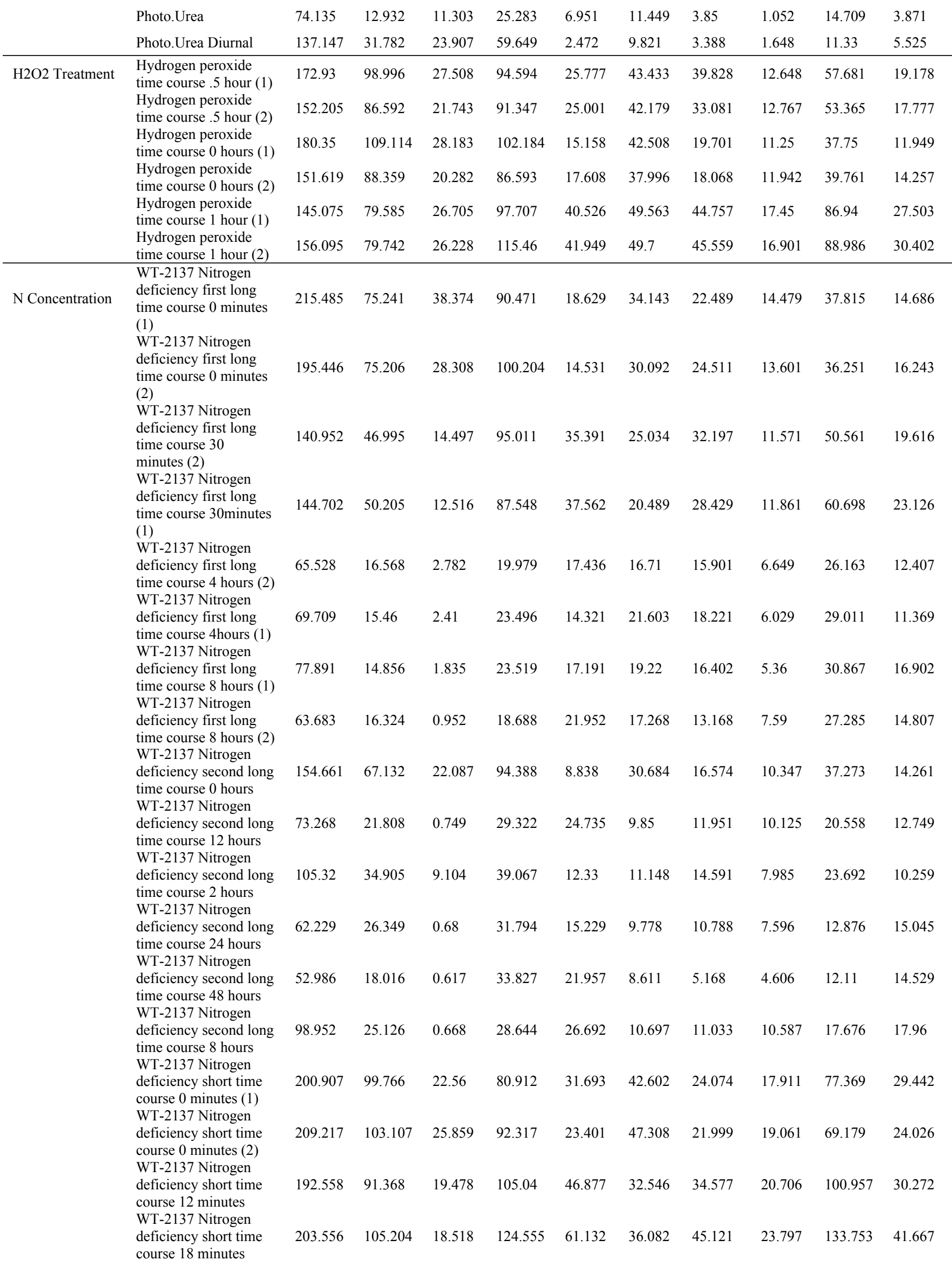


WT-2137 Nitrogen deficiency short time course 2 minutes

WT-2137 Nitrogen

deficiency short time course 24 minutes

WT-2137 Nitrogen

deficiency short time

course 30 minutes

WT-2137 Nitrogen

deficiency short time

course 4 minutes

WT-2137 Nitrogen

deficiency short time

course 45 minutes

WT-2137 Nitrogen

deficiency short time

course 60 minutes

WT-2137 Nitrogen

deficiency short time

course 8 minutes

\begin{tabular}{|c|c|c|c|c|c|c|c|c|c|}
\hline 202.748 & 97.582 & 20.896 & 78.682 & 33.509 & 34.465 & 23.783 & 16.844 & 71.042 & 24.969 \\
\hline 203.446 & 108.622 & 19.14 & 134.02 & 70.348 & 35.731 & 47.48 & 23.454 & 144.739 & 48.211 \\
\hline 189.129 & 102.947 & 16.01 & 186.383 & 92.807 & 33.429 & 45.563 & 26.786 & 119.117 & 43.786 \\
\hline 194.451 & 94.272 & 27.05 & 91.424 & 38.795 & 35.275 & 28.136 & 18.109 & 73.134 & 27.582 \\
\hline 177.551 & 76.596 & 19.434 & 166.988 & 81.157 & 22.445 & 27.728 & 25.82 & 68.038 & 30.941 \\
\hline 127.989 & 53.496 & 23.004 & 112.61 & 41.323 & 16.8 & 19.695 & 16.724 & 37.913 & 19.724 \\
\hline 203.241 & 96.809 & 20.115 & 92.706 & 37.842 & 35.502 & 27.901 & 16.873 & 88.576 & 27.233 \\
\hline
\end{tabular}

$[\mathbf{M e J A}]=\square 0 \mathrm{mM} \mathbf{\square} 1 \mathrm{mM}$

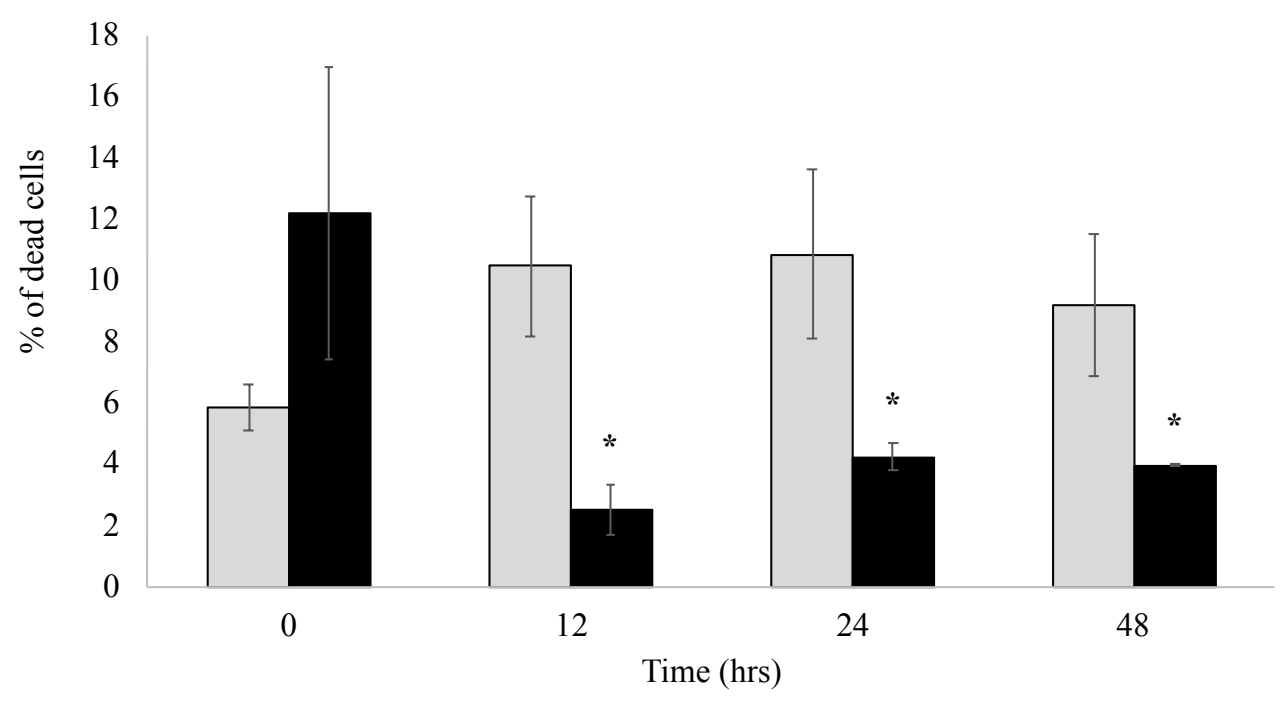

Figure A1. Percentage of dead cells in cultures of control $(0 \mathrm{mM})$ and $1 \mathrm{mM}$ MeJA treated cells. The initial 0 hour represents the time at which the cells were treated with MeJA. $C$. reinhardtii cells were stained with the LIVE/DEAD ${ }^{\mathrm{TM}}$ Fixable Violet Dead Cell Stain Kit (ThermoFisher) and then analysed by flow cytometry. Mean \pm SEM is shown $(n=3)$ and unpaired $t$-test determine statistical significance between the control $(0 \mathrm{mM})$ and the $1 \mathrm{mM}$ treatment $(\mathrm{p}<0.05[*])$. 


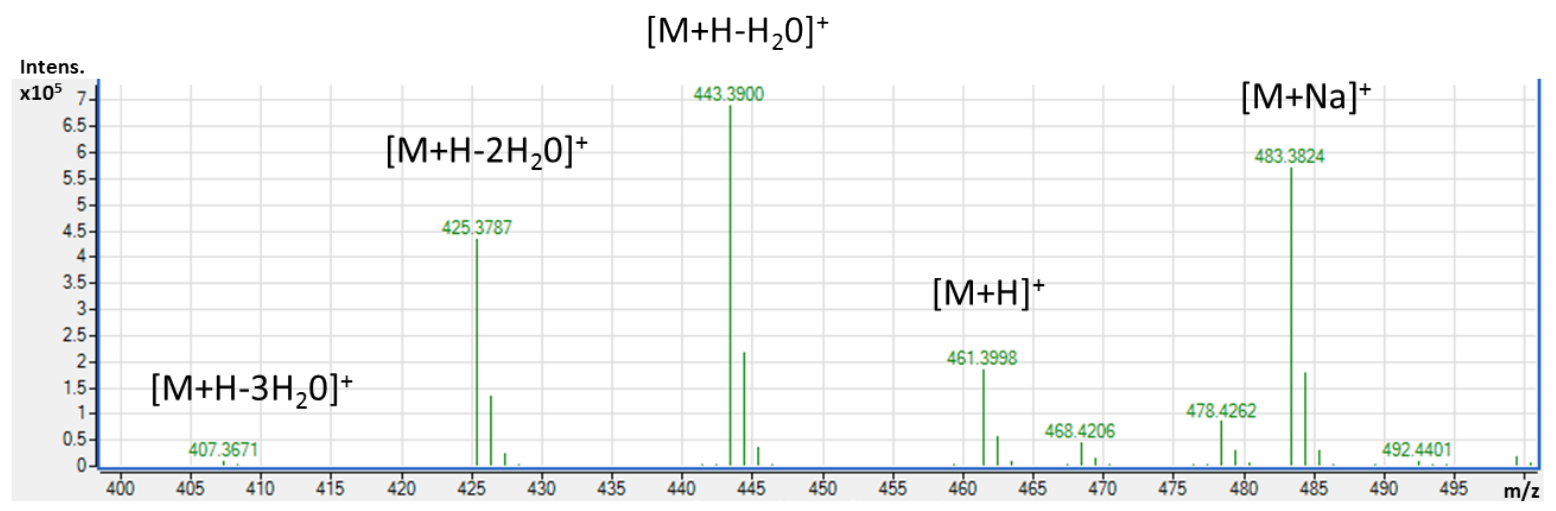

Figure A2. Mass spectrum of the $\mathrm{C}_{30} \mathrm{H}_{52} \mathrm{O}_{3}$ molecules.

\section{REFERENCES}

[1] C.E. Vickers, J.B.Y.H. Behrendorff, M. Bongers, T.C.R. Brennan, M. Bruschi, L.K.

Nielsen, Production of Industrially Relevant Isoprenoid Compounds in Engineered Microbes, in: B. Kamm (Ed.) Microorganisms in Biorefineries, Springer Berlin Heidelberg, Berlin, Heidelberg, 2015, pp. 303-334.

[2] C.E. Vickers, T.C. Williams, B. Peng, J. Cherry, Recent advances in synthetic biology for engineering isoprenoid production in yeast, Current opinion in chemical biology, 40 (2017) 47-56.

[3] R.C. Misra, P. Maiti, C.S. Chanotiya, K. Shanker, S. Ghosh, Methyl jasmonate-elicited transcriptional responses and pentacyclic triterpene biosynthesis in sweet basil, Plant Physiol, $164(2014)$ 1028-1044.

[4] T. Moses, J. Pollier, J.M. Thevelein, A. Goossens, Bioengineering of plant (tri)terpenoids: from metabolic engineering of plants to synthetic biology in vivo and in vitro, The New phytologist, 200 (2013) 27-43. 
[5] A.L. Meadows, K.M. Hawkins, Y. Tsegaye, E. Antipov, Y. Kim, L. Raetz, R.H. Dahl, A. Tai, T. Mahatdejkul-Meadows, L. Xu, L. Zhao, M.S. Dasika, A. Murarka, J. Lenihan, D. Eng, J.S. Leng, C.-L. Liu, J.W. Wenger, H. Jiang, L. Chao, P. Westfall, J. Lai, S. Ganesan, P. Jackson, R. Mans, D. Platt, C.D. Reeves, P.R. Saija, G. Wichmann, V.F. Holmes, K. Benjamin, P.W. Hill, T.S. Gardner, A.E. Tsong, Rewriting yeast central carbon metabolism for industrial isoprenoid production, Nature, 537 (2016) 694.

[6] N. Yan, C. Fan, Y. Chen, Z. Hu, The Potential for Microalgae as Bioreactors to Produce Pharmaceuticals, International journal of molecular sciences, 17 (2016) 962.

[7] F.K. Davies, R.E. Jinkerson, M.C. Posewitz, Toward a photosynthetic microbial platform for terpenoid engineering, Photosynthesis Research, 123 (2015) 265-284.

[8] C. Halfmann, L. Gu, W. Gibbons, R. Zhou, Genetically engineering cyanobacteria to convert $\mathrm{CO}(2)$, water, and light into the long-chain hydrocarbon farnesene, Applied microbiology and biotechnology, 98 (2014) 9869-9877.

[9] K.J. Lauersen, T. Baier, J. Wichmann, R. Wordenweber, J.H. Mussgnug, W. Hubner, T. Huser, O. Kruse, Efficient phototrophic production of a high-value sesquiterpenoid from the eukaryotic microalga Chlamydomonas reinhardtii, Metabolic engineering, 38 (2016) 331-343. [10] S. D'Adamo, G. Schiano di Visconte, G. Lowe, J. Szaub-Newton, T. Beacham, A. Landels, M.J. Allen, A. Spicer, M. Matthijs, Engineering The Unicellular Alga Phaeodactylum tricornutum For High-Value Plant Triterpenoid Production, Plant biotechnology journal, In press (2018).

[11] M. Lohr, J. Schwender, J.E. Polle, Isoprenoid biosynthesis in eukaryotic phototrophs: a spotlight on algae, Plant science : an international journal of experimental plant biology, 185$186(2012) 9-22$. 
[12] K.J. Lauersen, J. Wichmann, T. Baier, S.C. Kampranis, I. Pateraki, B.L. Møller, O.

Kruse, Phototrophic production of heterologous diterpenoids and a hydroxy-functionalized derivative from Chlamydomonas reinhardtii, Metabolic engineering, 49 (2018) 116-127.

[13] J. Wichmann, T. Baier, E. Wentnagel, K.J. Lauersen, O. Kruse, Tailored carbon partitioning for phototrophic production of (E)-alpha-bisabolene from the green microalga Chlamydomonas reinhardtii, Metabolic engineering, 45 (2018) 211-222.

[14] K. Vavitsas, E.Ø. Rue, L.K. Stefánsdóttir, T. Gnanasekaran, A. Blennow, C. Crocoll, S. Gudmundsson, P.E. Jensen, Responses of Synechocystis sp. PCC 6803 to heterologous biosynthetic pathways, Microbial Cell Factories, 16 (2017) 140.

[15] L. Pauwels, K. Morreel, E. De Witte, F. Lammertyn, M. Van Montagu, W. Boerjan, D. Inze, A. Goossens, Mapping methyl jasmonate-mediated transcriptional reprogramming of metabolism and cell cycle progression in cultured Arabidopsis cells, Proceedings of the National Academy of Sciences of the United States of America, 105 (2008) 1380-1385. [16] J.J. Cheong, Y.D. Choi, Methyl jasmonate as a vital substance in plants, Trends in genetics : TIG, 19 (2003) 409-413.

[17] H. Gundlach, M.J. Müller, T.M. Kutchan, M.H. Zenk, Jasmonic acid is a signal transducer in elicitor-induced plant cell cultures, Proceedings of the National Academy of Sciences, 89 (1992) 2389-2393.

[18] L. Pauwels, D. Inzé, A. Goossens, Jasmonate-inducible gene: what does it mean?, Trends in Plant Science, 14 (2009) 87-91.

[19] H. Suzuki, M.S.S. Reddy, M. Naoumkina, N. Aziz, G.D. May, D.V. Huhman, L.W. Sumner, J.W. Blount, P. Mendes, R.A. Dixon, Methyl jasmonate and yeast elicitor induce differential transcriptional and metabolic re-programming in cell suspension cultures of the model legume Medicago truncatula, Planta, 220 (2005) 696-707. 
[20] J. Shi, C. Ma, D. Qi, H. Lv, T. Yang, Q. Peng, Z. Chen, Z. Lin, Transcriptional responses and flavor volatiles biosynthesis in methyl jasmonate-treated tea leaves, BMC Plant Biology, $15(2015) 233$.

[21] G. Sun, Y. Yang, F. Xie, J.F. Wen, J. Wu, I.W. Wilson, Q. Tang, H. Liu, D. Qiu, Deep sequencing reveals transcriptome re-programming of Taxus $\mathrm{x}$ media cells to the elicitation with methyl jasmonate, PLoS One, 8 (2013) e62865.

[22] V. Courdavault, M. Clastre, A.J. Simkin, N. Giglioli-Guivarc'h, Prenylated Proteins Are Required for Methyl-Jasmonate-Induced Monoterpenoid Indole Alkaloids Biosynthesis in Catharanthus roseus, in: T.J. Bach, M. Rohmer (Eds.) Isoprenoid Synthesis in Plants and Microorganisms: New Concepts and Experimental Approaches, Springer New York, New York, NY, 2013, pp. 285-296.

[23] D. Yang, P. Ma, X. Liang, Z. Wei, Z. Liang, Y. Liu, F. Liu, PEG and ABA trigger methyl jasmonate accumulation to induce the MEP pathway and increase tanshinone production in Salvia miltiorrhiza hairy roots, Physiologia plantarum, 146 (2012) 173-183. [24] R.A. Patil, S.K. Lenka, J. Normanly, E.L. Walker, S.C. Roberts, Methyl jasmonate represses growth and affects cell cycle progression in cultured Taxus cells, Plant cell reports, 33 (2014) 1479-1492.

[25] J.-E. Lee, Y.U. Cho, K.H. Kim, D.Y. Lee, Distinctive metabolomic responses of Chlamydomonas reinhardtii to the chemical elicitation by methyl jasmonate and salicylic acid, Process Biochemistry, 51 (2016) 1147-1154.

[26] E.H. Harris, The Chlamydomonas Sourcebook (Second Edition), Vol. 1: Introduction to Chlamydomonas and Its Laboratory Use, 2nd Edition ed., Academic Press2009. [27] J. Pollier, E. Vancaester, U. Kuzhiumparambil, C.E. Vickers, K. Vandepoele, A. Goossens, M. Fabris, A widespread alternative squalene epoxidase participates in eukaryote steroid biosynthesis, Nature Microbiology, 4 (2019) 226-233. 
[28] A.B. Canelas, C. Ras, A. ten Pierick, J.C. van Dam, J.J. Heijnen, W.M. van Gulik, Leakage-free rapid quenching technique for yeast metabolomics, Metabolomics, 4 (2008) 226-239.

[29] L. Henneman, A.G. van Cruchten, S.W. Denis, M.W. Amolins, A.T. Placzek, R.A. Gibbs, W. Kulik, H.R. Waterham, Detection of nonsterol isoprenoids by HPLC-MS/MS, Analytical biochemistry, 383 (2008) 18-24.

[30] S.A. Bustin, V. Benes, J.A. Garson, J. Hellemans, J. Huggett, M. Kubista, R. Mueller, T. Nolan, M.W. Pfaffl, G.L. Shipley, J. Vandesompele, C.T. Wittwer, The MIQE guidelines: minimum information for publication of quantitative real-time PCR experiments, Clinical chemistry, 55 (2009) 611-622.

[31] B. Thornton, C. Basu, Real-time PCR (qPCR) primer design using free online software, Biochemistry and molecular biology education : a bimonthly publication of the International Union of Biochemistry and Molecular Biology, 39 (2011) 145-154.

[32] T. Zhao, W. Wang, X. Bai, Y. Qi, Gene silencing by artificial microRNAs in Chlamydomonas, The Plant journal : for cell and molecular biology, 58 (2009) 157-164.

[33] L. Whitney, G. Novi, P. Perata, E. Loreti, Distinct Mechanisms Regulating Gene Expression Coexist within the Fermentative Pathways in Chlamydomonas reinhardtii, The Scientific World Journal, 2012 (2012) 9.

[34] M. Pape, C. Lambertz, T. Happe, A. Hemschemeier, Differential Expression of the Chlamydomonas [FeFe]-Hydrogenase-Encoding HYDA1 Gene Is Regulated by the COPPER RESPONSE REGULATOR1, Plant Physiol., 159 (2012) 1700-1712.

[35] M. Kajikawa, S. Kinohira, A. Ando, M. Shimoyama, M. Kato, H. Fukuzawa, Accumulation of Squalene in a Microalga Chlamydomonas reinhardtii by Genetic Modification of Squalene Synthase and Squalene Epoxidase Genes, PLOS ONE, 10 (2015) e0120446. 
[36] M. Pfaffl, A new mathematical model for relative quantification in real-time RT-PCR, Nucleic Acids Research, 29 (2001) 2002-2007.

[37] A. Radonić, S. Thulke, I.M. Mackay, O. Landt, W. Siegert, A. Nitsche, Guideline to reference gene selection for quantitative real-time PCR, Biochemical and Biophysical Research Communications, 313 (2004) 856-862.

[38] L. Pauwels, A. Goossens, The JAZ Proteins: A Crucial Interface in the Jasmonate Signaling Cascade, The Plant cell, 23 (2011) 3089.

[39] J. Mach, The Jasmonate Receptor: Protein Modeling and Photoaffinity Labeling Reveal That the CORONATINE INSENSITIVE1 Protein Binds Jasmonoyl-Isoleucine and Coronatine, The Plant cell, 21 (2009) 2192-2192.

[40] M.D. Petroski, R.J. Deshaies, Function and regulation of cullin-RING ubiquitin ligases, Nature reviews. Molecular cell biology, 6 (2005) 9-20.

[41] N.T. Thanh, H.N. Murthy, K.W. Yu, E.J. Hahn, K.Y. Paek, Methyl jasmonate elicitation enhanced synthesis of ginsenoside by cell suspension cultures of Panax ginseng in 5-1 balloon type bubble bioreactors, Appl Microbiol Biotechnol, 67 (2005) 197-201.

[42] A. Swiatek, M. Lenjou, D. Van Bockstaele, D. Inze, H. Van Onckelen, Differential effect of jasmonic acid and abscisic acid on cell cycle progression in tobacco BY-2 cells, Plant Physiol, 128 (2002) 201-211.

[43] S. Jung, Effect of chlorophyll reduction in Arabidopsis thaliana by methyl jasmonate or norflurazon on antioxidant systems, Plant Physiology and Biochemistry, 42 (2004) 225-231. [44] K.M. Nkembo, J.-B. Lee, T. Hayashi, Selective Enhancement of Scopadulcic Acid B Production in the Cultured Tissues of $<\mathrm{i}>$ Scoparia dulcis $</ \mathbf{i}>$ by Methyl Jasmonate, Chemical and Pharmaceutical Bulletin, 53 (2005) 780-782. 
[45] P. Kumari, C.R.K. Reddy, B. Jha, Methyl Jasmonate-Induced Lipidomic and Biochemical Alterations in the Intertidal Macroalga Gracilaria dura (Gracilariaceae, Rhodophyta), Plant and Cell Physiology, 56 (2015) 1877-1889.

[46] B.M. Lange, T. Rujan, W. Martin, R. Croteau, Isoprenoid biosynthesis: The evolution of two ancient and distinct pathways across genomes, Proceedings of the National Academy of Sciences of the United States of America, 97 (2000) 13172-13177.

[47] E. Cordoba, M. Salmi, P. Leon, Unravelling the regulatory mechanisms that modulate the MEP pathway in higher plants, J Exp Bot, 60 (2009) 2933-2943.

[48] E. Vranová, D. Coman, W. Gruissem, Network Analysis of the MVA and MEP Pathways for Isoprenoid Synthesis, Annual Review of Plant Biology, 64 (2013) 665-700. [49] J.M. Estevez, A. Cantero, A. Reindl, S. Reichler, P. Leon, 1-Deoxy-D-xylulose-5phosphate synthase, a limiting enzyme for plastidic isoprenoid biosynthesis in plants, The Journal of biological chemistry, 276 (2001) 22901-22909.

[50] E.M. Enfissi, P.D. Fraser, L.M. Lois, A. Boronat, W. Schuch, P.M. Bramley, Metabolic engineering of the mevalonate and non-mevalonate isopentenyl diphosphate-forming pathways for the production of health-promoting isoprenoids in tomato, Plant biotechnology journal, 3 (2005) 17-27.

[51] W.L. Morris, L.J. Ducreux, P. Hedden, S. Millam, M.A. Taylor, Overexpression of a bacterial 1-deoxy-D-xylulose 5-phosphate synthase gene in potato tubers perturbs the isoprenoid metabolic network: implications for the control of the tuber life cycle, J Exp Bot, 57 (2006) 3007-3018.

[52] A. Banerjee, T.D. Sharkey, Methylerythritol 4-phosphate (MEP) pathway metabolic regulation, Natural Product Reports, 31 (2014) 1043-1055.

[53] Y. Xiao, T. Savchenko, E.E. Baidoo, W.E. Chehab, D.M. Hayden, V. Tolstikov, J.A. Corwin, D.J. Kliebenstein, J.D. Keasling, K. Dehesh, Retrograde signaling by the plastidial 
metabolite MEcPP regulates expression of nuclear stress-response genes, Cell, 149 (2012) $1525-1535$.

[54] M. Rodriguez-Concepcion, A. Boronat, Elucidation of the methylerythritol phosphate pathway for isoprenoid biosynthesis in bacteria and plastids. A metabolic milestone achieved through genomics, Plant Physiol, 130 (2002) 1079-1089.

[55] G.M. Estavillo, K.X. Chan, S.Y. Phua, B.J. Pogson, Reconsidering the nature and mode of action of metabolite retrograde signals from the chloroplast, Frontiers in plant science, 3 (2012) 300 .

[56] K. Zhou, R. Zou, G. Stephanopoulos, H.P. Too, Metabolite profiling identified methylerythritol cyclodiphosphate efflux as a limiting step in microbial isoprenoid production, PLoS One, 7 (2012) e47513.

[57] K.M. Brumfield, S.M. Laborde, J.V. Moroney, A model for the ergosterol biosynthetic pathway in Chlamydomonas reinhardtii, European Journal of Phycology, 52 (2017) 64-74. [58] J.Y. Han, J.G. In, Y.S. Kwon, Y.E. Choi, Regulation of ginsenoside and phytosterol biosynthesis by RNA interferences of squalene epoxidase gene in Panax ginseng, Phytochemistry, 71 (2010) 36-46.

[59] H. Suzuki, L. Achnine, R. Xu, S.P. Matsuda, R.A. Dixon, A genomics approach to the early stages of triterpene saponin biosynthesis in Medicago truncatula, The Plant journal : for cell and molecular biology, 32 (2002) 1033-1048.

[60] J.Y. Han, H.J. Kim, Y.S. Kwon, Y.E. Choi, The Cyt P450 enzyme CYP716A47 catalyzes the formation of protopanaxadiol from dammarenediol-II during ginsenoside biosynthesis in Panax ginseng, Plant \& cell physiology, 52 (2011) 2062-2073.

[61] J.Y. Oh, Y.-J. Kim, M.-G. Jang, S.C. Joo, W.-S. Kwon, S.-Y. Kim, S.-K. Jung, D.-C. Yang, Investigation of ginsenosides in different tissues after elicitor treatment in Panax ginseng, Journal of Ginseng Research, 38 (2014) 270-277. 
[62] S. Mangas, M. Bonfill, L. Osuna, E. Moyano, J. Tortoriello, R.M. Cusido, M.T. Pinol, J.

Palazon, The effect of methyl jasmonate on triterpene and sterol metabolisms of Centella asiatica, Ruscus aculeatus and Galphimia glauca cultured plants, Phytochemistry, 67 (2006) 2041-2049.

[63] O.-T. Kim, M.-Y. Kim, S.-J. Hwang, J.-C. Ahn, B. Hwang, Cloning and molecular analysis of cDNA encoding cycloartenol synthase fromCentella asiatica (L.) urban, Biotechnology and Bioprocess Engineering, 10 (2005) 16. 